\title{
The Medical World is Flat Too
}

\author{
Donald D. Trunkey
}

Published online: 27 March 2008

(c) Société Internationale de Chirurgie 2008

\begin{abstract}
Background Tom Friedman, in his book, "The World is Flat," makes a very persuasive argument that our current economic policy transcends national boundaries. Friedman describes various processes that prove his point. These include workflow software, open sourcing, outsourcing, offshoring, supply chaining, in-sourcing, and informing. The United States already outsources surgery. In this article, I give the retail surgical rates and discount rates of the US, and compare them to that of the same surgery in India, Thailand, and Singapore. Supply chaining is another example that applies to the field of medicine, particularly pharmaceuticals. Most pharmaceutical firms are located in developed countries, but $80 \%$ of the pharmaceuticals are manufactured in developing countries. A phenomenon that may be unique to the United States is that we off-shore some of our diagnostic capabilities, primarily during out nighttime hours. Under the rubric of "Nighthawk," X-rays, including CT scans, are digitized and sent to Australia, Spain, and other countries during our nighttime hours. A diagnosis is made and sent back to the referring hospital in the US, usually within 30 minutes. I think an argument can be made that almost all of the issues that Friedman talks about in his book, apply to the field of medicine. Trauma care is a microcosm
\end{abstract}

This article is the synthesis of two lectures presented at the meeting of the International Society for Surgery in Montreal, August 28 and 29, 2007. The first lecture was the American College of Surgeons' Lecture entitled "The Medical World is Flat Too." The second lecture was The Donald D. Trunkey Lecture entitled "Improving Trauma Care in Developing Countries."

D. D. Trunkey $(\bowtie)$

Department of Surgery, Oregon Health and Science University, 3181 SW Sam Jackson Park Road, L223, Portland, OR 97239, USA

e-mail: trunkeyd@ohsu.edu of medicine and uses most of the resources shared by other specialties. The trauma patient has to be identified and ambulances called, usually by 911 or similar numeric systems in other countries. The patient is transported to an emergency room, and if the injury is severe, admitted for acute care, which often requires surgery, intensive care, and ward care. When possible, the patient is discharged home, but is often sent to a rehabilitation facility or a nursing home. To improve trauma care and outcome, surgeons have turned to the organization and system approach that has been so successful in military situations.

Materials and methods An extensive review of the surgical and public health papers relating to trauma was carried out. This article is an inventory of how trauma systems are progressing in different countries and whether they are effective. Some of the pitfalls that globalization may bring are also discussed.

Results and conclusions For the last 100 years, there has been gradual improvement in care of the civilian patients, as a system approach similar to the military care of injured patients has been introduced and matured. These systems include prehospital care, acute care, rehabilitation; ideally, using a public health approach, preventive components are also utilized. Research is another component that is key in improving patient outcomes.

\section{Introduction}

In his book The World is Flat, Tom Friedman has as an underlying thesis that our current economic policy transcends national boundaries [1]. The economic processes include workflow software, open sourcing, outsourcing, off-shoring, supply-chaining, in-sourcing, and informing. 
Table 1 Charges for surgical procedures in the United States ${ }^{a}$

\begin{tabular}{|c|c|c|c|c|c|}
\hline & U.S. insurers' costs & U.S. retail & India & Thailand & Singapore \\
\hline Angioplasty & $25,704-37,128$ & $57,262-82,111$ & 11,000 & 13,000 & 13,000 \\
\hline Gastric bypass & $27,717-40,035$ & $7,988-69,316$ & 11,000 & 15,000 & 15,000 \\
\hline Heart bypass & $54,741-79,071$ & $122,424-176,835$ & 10,000 & 12,000 & 20,000 \\
\hline Heartl valve & $71,401-103,136$ & $159,326-230,138$ & 9,500 & 10,500 & 13,000 \\
\hline Hip replacement & $18,241-26,407$ & $43,780-63,238$ & 9,000 & 12,000 & 12,000 \\
\hline Knee replacement & $17,627-25,467$ & $40,640-58,702$ & 8,500 & 10,000 & 13,000 \\
\hline Hysterectomy & $9,591-13,854$ & $20,416-29,489$ & 2,900 & 4,500 & - \\
\hline Spinal fusion & $25,302-36,547$ & $62,778-90,699$ & 5,500 & 7,000 & 9,000 \\
\hline
\end{tabular}

a The table is modified from a table in a December 2006 Time magazine article and includes data from [1] and the book Critical Condition [2]. The second column gives insurers' discounted rates and the third column gives the range of retail or nondiscounted rates. The fourth, fifth, and sixth columns give typical costs to patients who go to India, Thailand, or Singapore for their surgery. These rates include airfare from the United States

He goes on to say that essentially this process cannot be stopped. It is my contention that the medical world is flat too. We are already outsourcing surgery (Table 1). The pharmaceutical industry, which is globally located in developed economies, obtains the manufactured drugs from low- and middle-income countries (supply chain). In the last few years, large medical conglomerates such as Health Care of America (HCA), Tenet, and Kaiser have established call centers in developing countries that answer inquiries from patients from the United States about appointments and even access to emergency rooms. Under the rubric Nighthawk, several countries in daylight time zones provide diagnostic radiology services during night hours in the United States. Increasingly, software for diagnostic imaging is being developed in India and Southeast Asia. Arguably, the globalization of medical care may make access better and supply cheaper products, but this all comes at a price [3].

\section{The problems}

To make an argument for the globalization of medicine, I would like to examine the impact of intentional and unintentional injuries on a worldwide basis. There is no better resource than the Global Burden of Disease Study by Murray and Lopez [4]. In their study they divided the world into developed and developing regions and divided the world into eight distinct economic regions (Fig. 1). In 1990, five million people worldwide are estimated to have died from intentional and unintentional injuries. The risk of injury death varies widely by region, age, and sex (Table 2). If one compares mortality from violent causes, injuries caused about $6 \%$ of all deaths in 1990 in the European market economies compared with $9-11 \%$ in other regions. It is particularly striking and problematic in sub-Saharan Africa and Latin America where 12-13\% of deaths are related to violence. It is primarily a problem in males, where

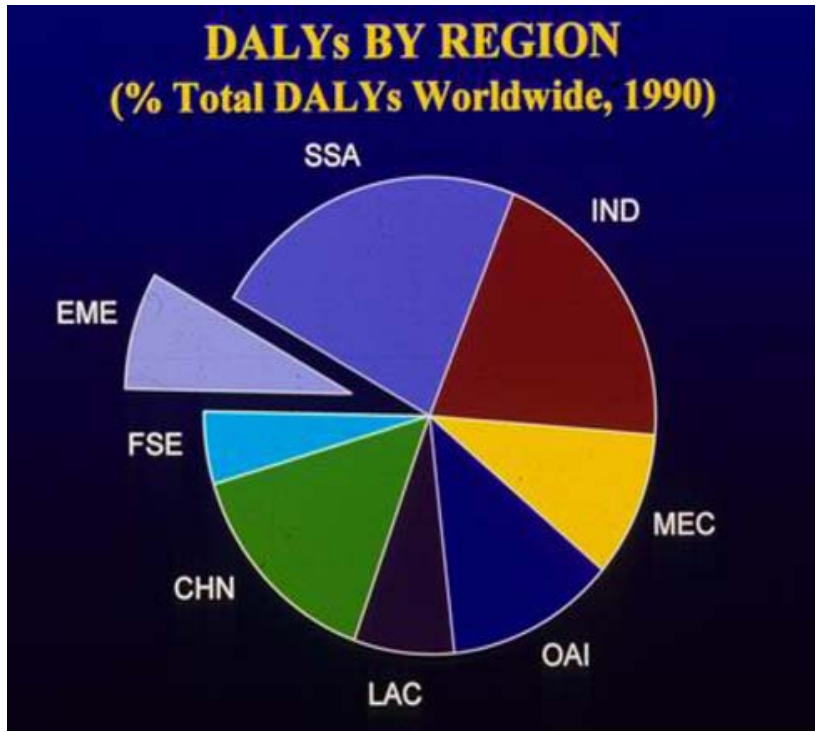

Fig. 1 Murray and Lopez [4]

Table 2 Intentional and unintentional injuries ${ }^{\mathrm{a}}$

- 1990-5 million people died-10\% of deaths

- $12.5 \%$ of male deaths

- $6 \%$ of deaths in EME

- $12-13 \%$ of deaths in SSA and LA

- 9-11\% in other regions

- Globally-30\% of male deaths 15-29 years

${ }^{a}$ From [4]

it accounts for $16-17 \%$ of deaths. Worldwide, road traffic accidents are the 9th cause of death. In developed regions, road traffic accidents are the 8th cause of death, and selfinflicted injuries are number 9 . In developing regions of the world, road traffic accidents are number 10 , and infectious diseases are the 4th, 6th, 8th, and 9th causes (diarrheal diseases, tuberculosis, measles, and malaria). 


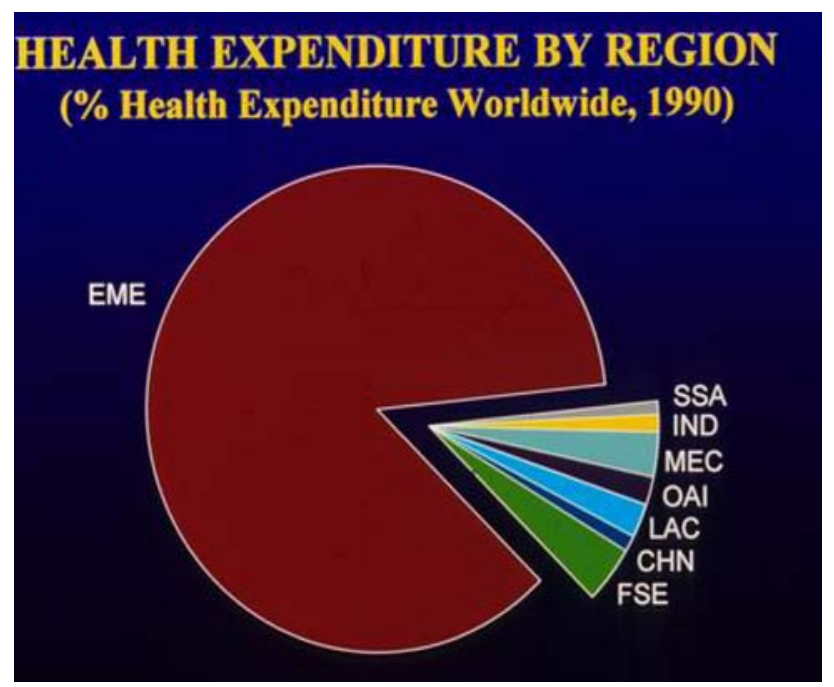

Fig. 2 Murray and Lopez [4]

In an attempt to quantify the burden of disease and injury of various human populations, Murray and Lopez [4] have used the concept of disability-adjusted life years (DALYs). DALYs is defined as the sum of life-years lost due to premature mortality and years lived with disability adjusted for severity. This obviously gives us a different perspective on how injury impacts negatively on individual lives and societal costs. Worldwide in 1990, road traffic accidents was the number 9 cause of DALYs. In developed regions, traffic accidents was the number 4 cause of DALYs, and self-inflicted injuries was number 9. In developing regions, road traffic accidents was number 11 , war was number 16 , violence was number 18 , and selfinflicted injuries was number 19. Murray and Lopez conclude that injuries play a surprisingly large role in the burden of disease. Overall, they account for $14.5 \%$ of the burden in developed regions and $15.2 \%$ in developing regions. It is noteworthy that there is variability across the eight economic regions in the world. The EME have less than $20 \%$ of the DALYs but use $80 \%$ of health resources (Fig. 2, Tables 3-7).

The lessons learned in the military conflicts of the 20th century have been applied to trauma care of civilians. However, the evolution of trauma care systems for civilians was accelerated in 1966 with the establishment of two trauma centers in the U.S. [5]. One of these trauma centers was started at San Francisco General Hospital under the leadership of William Blaisdell, and the other was started at Cook County Hospital in Chicago under the leadership of Robert Freeark. The rationale for these two trauma centers was multiple. Titles 18 and 19 (Medicare and Medicaid) had just been introduced and the old city and county hospitals were essentially without patients. At the same time, urban violence was on the rise, primarily as a
Table 3 Causes of DALYs in descending order 1990, both sexes ${ }^{\text {a }}$

\begin{tabular}{llrl}
\hline Rank & Disease or injury & $\begin{array}{l}\text { Deaths } \\
\text { (thousands) }\end{array}$ & $\begin{array}{l}\text { \% of } \\
\text { Total }\end{array}$ \\
\hline & World-all causes & $1,379,238$ & \\
1 & Lower respiratory disease & 112,898 & 8.2 \\
2 & Diarrheal diseases & 99,633 & 7.2 \\
3 & Conditions arising during & 92,313 & 6.7 \\
& the perinatal period & & \\
4 & Unipolar major depression & 50,810 & 3.7 \\
5 & Ischemic heart disease & 46,699 & 3.4 \\
6 & Cerebrovascular disease & 38,523 & 2.8 \\
7 & Tuberculosis & 38,426 & 2.8 \\
8 & Measles & 36,520 & 2.7 \\
9 & Road traffic accidents & 34,317 & 2.5 \\
10 & Congenital anomalies & 32,921 & 2.4 \\
11 & Malaria & 31,706 & 2.4 \\
12 & COPD & 29,136 & 2.1 \\
13 & Falls & 26,680 & 1.9 \\
14 & Iron-deficiency anemia & 24,613 & 1.8 \\
15 & Protein-energy malnutrition & 20,957 & 1.5 \\
16 & War & 20,019 & 1.5 \\
17 & Self-inflicted injuries & 18,967 & 1.4 \\
18 & Tetanus & 17,517 & 1.3 \\
19 & Violence & 17,472 & 1.3 \\
20 & Alcohol & 16,661 & 1.2 \\
\hline COPD & & & \\
& & &
\end{tabular}

$\mathrm{COPD}=$ chronic obstructive pulmonary disease DALY $=$ disability adjusted life years

${ }^{\text {a }}$ From [4]

consequence of the increase in urban ghettos and an increase in drug-related violence. The leaders of these two trauma centers recognized the need for a systematic approach to trauma care and the concept of a trauma center was pivotal to this overall need.

Shortly after these two centers were started, the political and administrative genius of R. Adams Cowley were combined when he established the Maryland system of trauma care, which eventually became a statewide system. The most remarkable development of a statewide trauma system occurred early in the 1970s in Germany [6]. At that time, road traffic accidents accounted for 18,000 deaths annually. Since 1975, this has been reduced to approximately 7,000 .

In 1976, the American College of Surgeons Committee on Trauma developed a formal outline of injury care called Optimal Criteria for Care of the Injured Patient. Subsequently, task forces of the American College of Surgeons Committee on Trauma met approximately every 4 years and updated their optimal criteria, which now are used extensively in establishing regional and state trauma systems. More recently, the American College of Surgeons Committee on Trauma, working with the American 
Table 4 Causes of DALYs in descending order 1990, both sexes ${ }^{\mathrm{a}}$

\begin{tabular}{|c|c|c|c|}
\hline Rank & Disease or injury & $\begin{array}{l}\text { Deaths } \\
\text { (thousands) }\end{array}$ & $\begin{array}{l}\% \text { of } \\
\text { Total }\end{array}$ \\
\hline & Developed regions-all causes & 160,994 & \\
\hline 1 & Ischemic heart disease & 15,950 & 9.9 \\
\hline 2 & Unipolar major depression & 9,780 & 6.1 \\
\hline 3 & Cerebrovascular disease & 9,425 & 5.9 \\
\hline 4 & Road traffic accidents & 7,064 & 4.4 \\
\hline 5 & Alcohol use & 6,446 & 4.0 \\
\hline 6 & Osteoarthritis & 4,681 & 2.9 \\
\hline 7 & Trachea, bronchus, and lung cancers & 4,587 & 2.9 \\
\hline 8 & $\begin{array}{l}\text { Dementia and other degenerative and } \\
\text { hereditary CNS disorders }\end{array}$ & 3,816 & 2.4 \\
\hline 9 & Self-inflicted injuires & 3,768 & 2.3 \\
\hline 10 & Congenital anomalies & 3,480 & 2.2 \\
\hline 11 & COPD & 3,365 & 2.1 \\
\hline 12 & $\begin{array}{l}\text { Conditions arising during the perinatal } \\
\text { period }\end{array}$ & 3,120 & 1.9 \\
\hline 13 & Schizophrenia & 3,106 & 1.9 \\
\hline 14 & Diabetes mellitus & 3,022 & 1.9 \\
\hline 15 & Bipolar disorder & 2,543 & 1.6 \\
\hline 16 & Falls & 2,448 & 1.5 \\
\hline 17 & Lower respiratory disease & 2,392 & 1.5 \\
\hline 18 & Cirrhosis of the liver & 2,345 & 1.5 \\
\hline 19 & Colon and rectum cancers & 2,298 & 1.4 \\
\hline 20 & Obsessive-compulsive disorder & 2,098 & 1.3 \\
\hline
\end{tabular}

COPD $=$ chronic obstructive pulmonary disease DALY $=$ disability adjusted life years; CNS = central nervous system

${ }^{a}$ From [4]

College of Emergency Physicians, has developed some new guidelines for trauma care systems. Under the new model, the system of trauma care is inclusive rather than exclusive. In the old system, only patients who were severely injured were treated at a trauma center. Under the new system, all patients, including those with moderate and minor injuries, are part of the model trauma care plan. The model trauma care system cares for patients whether they are in an urban or a rural setting, and the providers have been expanded to include teams and system management in prehospital care, trauma care facilities, and rehabilitation services. The components of this system include leadership; system development; legislation; finance; public information, education, and prevention; human resources; prehospital care with the subcomponents of communication; medical direction; triage and transport; definitive care, including the subcomponents of trauma facilities, interfacility transfer, and rehabilitation; and finally a quality improvement program that evaluates all of these components. Other contributions by the American College of Surgeons Committee on Trauma include introduction of the Advanced Trauma Life Support courses, establishment
Table 5 Causes of DALYs in descending order 1990, both sexes ${ }^{\mathrm{a}}$

\begin{tabular}{llrl}
\hline Rank & Disease or injury & $\begin{array}{l}\text { Deaths } \\
\text { (thousands) }\end{array}$ & $\begin{array}{r}\% \text { of } \\
\text { Total }\end{array}$ \\
\hline & Developing regions-all causes & $1,218,244$ & \\
1 & Lower respiratory disease & 110,506 & 9.1 \\
2 & Diarrheal diseases & 99,168 & 8.1 \\
3 & Conditions arising during & 89,193 & 7.3 \\
& the perinatal period & & \\
4 & Unipolar major depression & 41,031 & 3.4 \\
5 & Tuberculosis & 37,930 & 3.1 \\
6 & Measles & 36,498 & 3.0 \\
7 & Malaria & 31,705 & 2.6 \\
8 & Ischemic heart disease & 30,749 & 2.5 \\
9 & Congenital anomalies & 29,441 & 2.4 \\
10 & Cerebrovascular disease & 29,099 & 2.4 \\
11 & Road traffic accidents & 27,253 & 2.2 \\
12 & COPD & 25,771 & 2.1 \\
13 & Falls & 24,232 & 2.0 \\
14 & Iron-deficiency anemia & 23,465 & 1.9 \\
15 & Protein-energy malnutrition & 20,758 & 1.7 \\
16 & War & 18,868 & 1.6 \\
17 & Tetanus & 17,513 & 1.4 \\
18 & Violence & 15,632 & 1.3 \\
19 & Self-inflicted injuries & 15,199 & 1.3 \\
20 & Drownings & 14,819 & 1.2 \\
\hline
\end{tabular}

$\mathrm{COPD}=$ chronic obstructive pulmonary disease DALY $=$ disability adjusted life years

${ }^{\text {a }}$ From [4]

of a national trauma registry (National Trauma Data Bank), and a national verification program. The latter is analogous to the old Hospital Standardization Program and verifies whether a hospital's trauma center meets the guidelines of the American College of Surgeons. This process is unique. The hospital is visited by two surgeons, often accompanied by a trauma nurse and occasionally by specialty surgeons, including pediatric surgeons or neurosurgeons. Part of the process includes reviewing medical records to assess the care of patients and whether appropriate peer review is being done.

Since 1984, more than 20 articles have been published showing that trauma systems benefit society by increasing the chances of survival when patients are treated in specialized centers [7]. In addition, two studies have shown that trauma systems also reduce trauma morbidity $[8,9]$. In 1988, a report card was issued on the current status and future challenges of trauma systems [10]. At that time an inventory was taken of all directors of state emergency medical services or of health departments who have responsibility over emergency and trauma planning. They were contacted by telephone in February 1987 and were asked eight specific questions about their state trauma 
Table 6 Fifteen most common causes of death worldwide by age group, $2002^{\mathrm{a}}$

\begin{tabular}{|c|c|c|c|c|c|c|c|}
\hline Rank & $0-4$ years & $5-14$ years & 15-29 years & 30-44 years & $45-59$ years & $\geq 60$ years & All ages \\
\hline 1 & $\begin{array}{l}\text { Lower respiratory } \\
\text { infections } \\
(1,890,008)\end{array}$ & $\begin{array}{l}\text { Childhood } \\
\text { cluster } \\
\text { diseases } \\
(219,434)\end{array}$ & $\begin{array}{l}\text { HIV/AIDS } \\
(707,277)\end{array}$ & $\begin{array}{l}\text { HIV/AIDS } \\
\qquad(1,178,856)\end{array}$ & $\begin{array}{l}\text { Ischemic heart } \\
\text { disease } \\
(1,043,978)\end{array}$ & $\begin{array}{l}\text { Ischemic heart } \\
\text { disease } \\
(5,812,863)\end{array}$ & $\begin{array}{l}\text { Ischemic heart } \\
\text { disease } \\
(7,153,056)\end{array}$ \\
\hline 2 & $\begin{array}{l}\text { Diarrheal } \\
\quad \text { diseases } \\
(1,577,891)\end{array}$ & $\begin{array}{c}\text { Road traffic } \\
\text { injuries } \\
(130,835)\end{array}$ & $\begin{array}{c}\text { Road traffic } \\
\text { injuries } \\
(302,208)\end{array}$ & $\begin{array}{c}\text { Tuberculosis } \\
(390,004)\end{array}$ & $\begin{array}{l}\text { Cerebrovascular } \\
\text { disease } \\
(623,099)\end{array}$ & $\begin{array}{l}\text { Cerebrovascular } \\
\text { disease } \\
(4,685,722)\end{array}$ & $\begin{array}{l}\text { Cerebrovascular } \\
\text { disease } \\
(5,489,591)\end{array}$ \\
\hline 3 & $\begin{array}{c}\text { Low birth weight } \\
(1,149,168)\end{array}$ & $\begin{array}{l}\text { Lower } \\
\text { respiratory } \\
\text { infections } \\
(127,782)\end{array}$ & $\begin{array}{l}\text { Self-inflicted } \\
\text { injuries } \\
(251,806)\end{array}$ & $\begin{array}{c}\text { Road traffic } \\
\text { injuries } \\
(285,457)\end{array}$ & $\begin{array}{c}\text { Tuberculosis } \\
(400,708)\end{array}$ & COPD $(2,396,739)$ & $\begin{array}{l}\text { Lower respiratory } \\
\text { infections } \\
(3,764,415)\end{array}$ \\
\hline 4 & $\begin{array}{l}\text { Malaria } \\
\qquad(1,098,446)\end{array}$ & $\begin{array}{l}\text { HIV/AIDS } \\
(108,090)\end{array}$ & $\begin{array}{c}\text { Tuberculosis } \\
(245,818)\end{array}$ & $\begin{array}{l}\text { Ischemic heart } \\
\text { disease } \\
(231,340)\end{array}$ & $\begin{array}{l}\text { HIV/AIDS } \\
(390,267)\end{array}$ & $\begin{array}{l}\text { Lower respiratory } \\
\text { infections } \\
(1,395,611)\end{array}$ & $\begin{array}{l}\text { HIV/AIDS } \\
\quad(2,818,762)\end{array}$ \\
\hline 5 & $\begin{array}{l}\text { Childhood cluster } \\
\text { diseases } \\
(1,046,177)\end{array}$ & $\begin{array}{l}\text { Drowning } \\
\quad(86,327)\end{array}$ & $\begin{array}{c}\text { Interpersonal } \\
\text { violence } \\
(216,169)\end{array}$ & $\begin{array}{l}\text { Self-inflicted } \\
\text { injuries } \\
(230,490)\end{array}$ & COPD $(309,726)$ & $\begin{array}{l}\text { Cancers of trachea, } \\
\text { bronchus, lung } \\
(261,860)\end{array}$ & COPD $(2,743,509)$ \\
\hline 6 & $\begin{array}{l}\text { Birth asphyxia } \\
\text { and birth } \\
\text { trauma } \\
(729,066)\end{array}$ & $\begin{array}{l}\text { Tropical cluster } \\
\text { diseases } \\
(35,454)\end{array}$ & $\begin{array}{l}\text { Lower } \\
\quad \text { respiratory } \\
\text { infections } \\
(92,522)\end{array}$ & $\begin{array}{c}\text { Interpersonal } \\
\text { violence } \\
(165,796)\end{array}$ & $\begin{array}{l}\text { Cancers of trachea, } \\
\text { bronchus, lung } \\
(261,860)\end{array}$ & $\begin{array}{l}\text { Diabetes mellitus } \\
\quad(749,977)\end{array}$ & $\begin{array}{l}\text { Diarrheal diseases } \\
(1,766,447)\end{array}$ \\
\hline 7 & $\begin{array}{l}\text { HIV/AIDS } \\
(370,706)\end{array}$ & Fires $(33,046)$ & Fires $(90,845)$ & $\begin{array}{l}\text { Cerebrovascular } \\
\text { disease } \\
(124,417)\end{array}$ & $\begin{array}{l}\text { Cirrhosis of liver } \\
(250,208)\end{array}$ & $\begin{array}{l}\text { Hypertensive heart } \\
\text { disease }(732,262)\end{array}$ & $\begin{array}{l}\text { Tuberculosis } \\
(1,605,063)\end{array}$ \\
\hline 8 & $\begin{array}{l}\text { Congenital heart } \\
\text { abnormalities } \\
(223,569)\end{array}$ & $\begin{array}{c}\text { Tuberculosis } \\
(32,762)\end{array}$ & $\begin{array}{l}\text { Drowning } \\
(87,499)\end{array}$ & $\begin{array}{l}\text { Cirrhosis of liver } \\
\quad(100,101)\end{array}$ & $\begin{array}{l}\text { Road traffic } \\
\text { injuries } \\
(221,776)\end{array}$ & $\begin{array}{c}\text { Stomach cancer } \\
(605,395)\end{array}$ & $\begin{array}{l}\text { Childhood cluster } \\
\text { diseases } \\
\quad(1,359,548)\end{array}$ \\
\hline 9 & $\begin{array}{l}\text { Protein-energy } \\
\text { malnutrition } \\
(138,197)\end{array}$ & $\begin{array}{l}\text { Protein-energy } \\
\text { malnutrition } \\
(30,763)\end{array}$ & War $(71,680)$ & $\begin{array}{l}\text { Lower } \\
\text { respiratory } \\
\text { infections } \\
(98,232)\end{array}$ & $\begin{array}{l}\text { Self-inflicted } \\
\text { injuries } \\
(189,215)\end{array}$ & $\begin{array}{c}\text { Tuberculosis } \\
(495,199)\end{array}$ & $\begin{array}{c}\text { Cancers of trachea, } \\
\text { bronchus, lung } \\
(1,238,417)\end{array}$ \\
\hline 10 & $\begin{array}{r}\text { STDs excluding } \\
\text { HIV }(67,871)\end{array}$ & $\begin{array}{r}\text { Meningitis } \\
(30,694)\end{array}$ & $\begin{array}{c}\text { Hypertensive } \\
\text { disorders } \\
(61,711)\end{array}$ & $\begin{array}{l}\text { Poisoning } \\
\quad(81,930)\end{array}$ & $\begin{array}{l}\text { Stomach cancer } \\
(185,188)\end{array}$ & $\begin{array}{l}\text { Colon or rectal } \\
\text { cancer }(476,902)\end{array}$ & Malaria $1,221,432$ ) \\
\hline 11 & $\begin{array}{r}\text { Meningitis } \\
(64,255)\end{array}$ & $\begin{array}{l}\text { Leukemia } \\
\quad(21,097)\end{array}$ & $\begin{array}{l}\text { Maternal } \\
\text { hemorrhage } \\
(56,233)\end{array}$ & Fires $(67,511)$ & $\begin{array}{c}\text { Liver cancer } \\
\quad(108,117)\end{array}$ & $\begin{array}{r}\text { Nephritis or } \\
\text { nephrosis } \\
(440,708)\end{array}$ & $\begin{array}{l}\text { Roadi traffic } \\
\text { injuries }(49,736)\end{array}$ \\
\hline 12 & $\begin{array}{l}\text { Drowning } \\
\quad(57,287)\end{array}$ & Falls $(20,084)$ & $\begin{array}{l}\text { Ischemic heart } \\
\text { disease } \\
(53,870)\end{array}$ & $\begin{array}{l}\text { Maternal } \\
\text { hemorrhage } \\
(63,191)\end{array}$ & $\begin{array}{l}\text { Diabetes mellitus } \\
\quad(175,423)\end{array}$ & $\begin{array}{l}\text { Alzheimer disease } \\
\text { and other } \\
\text { dementias } \\
(382,339)\end{array}$ & $\begin{array}{l}\text { Low birth weight } \\
\quad(1,149,172)\end{array}$ \\
\hline 13 & $\begin{array}{c}\text { Road traffic } \\
\text { injuries } \\
(49,736)\end{array}$ & $\begin{array}{c}\text { Interpersonal } \\
\text { violence } \\
(18,551)\end{array}$ & $\begin{array}{l}\text { Poisoning } \\
\quad(52,956)\end{array}$ & War $(61,018)$ & $\begin{array}{l}\text { Lower respiratory } \\
\text { infections } \\
(160,259)\end{array}$ & $\begin{array}{c}\text { Liver cancer } \\
(367,503)\end{array}$ & $\begin{array}{l}\text { Diabetes mellitus } \\
\quad(982,175)\end{array}$ \\
\hline 14 & $\begin{array}{l}\text { Endocrine } \\
\text { disorders } \\
(42,619)\end{array}$ & $\begin{array}{l}\text { Poisoning } \\
\quad(18,529)\end{array}$ & $\begin{array}{l}\text { Childhood } \\
\text { cluster } \\
\text { diseases } \\
(48,101)\end{array}$ & $\begin{array}{l}\text { Drowning } \\
\quad(56,744)\end{array}$ & $\begin{array}{c}\text { Breast cancer } \\
(147,489)\end{array}$ & $\begin{array}{l}\text { Cirrhosis of liver } \\
(366,417)\end{array}$ & $\begin{array}{l}\text { Hypertensive heart } \\
\text { disease } \\
(903,612)\end{array}$ \\
\hline 15 & $\begin{array}{c}\text { Tuberculosis } \\
(40,574)\end{array}$ & $\begin{array}{l}\text { Malaria } \\
\quad(15,372)\end{array}$ & $\begin{array}{l}\text { Abortion } \\
\quad(43,782)\end{array}$ & $\begin{array}{c}\text { Liver cancer } \\
(55,486)\end{array}$ & $\begin{array}{l}\text { Hypertensive heart } \\
\text { disease } \\
(129.634)\end{array}$ & $\begin{array}{l}\text { Esophageal cancer } \\
\quad(318,112)\end{array}$ & $\begin{array}{l}\text { Self-inflicted } \\
\quad \text { injuries } \\
(874,955)\end{array}$ \\
\hline
\end{tabular}

${ }^{\mathrm{a}}$ From [4]

system. Only two states, Maryland and Virginia, had all eight essential components of a regional trauma system. Nineteen states and Washington, DC, either had incomplete statewide coverage or lacked essential components. Not limiting the number of trauma centers in a region was the most common deficient criterion. 
Table 7 Regions GBD

\begin{tabular}{ll}
\hline EME & Established Market Economies \\
FSE & Formerly Socialist Economies Europe \\
CHN & China \\
LAC & Latin America/Caribbean \\
OAI & Other Asia and Islands \\
MEC & Middle Eastern Crescent \\
IND & India \\
SSA & Sub-Saharan Africa \\
\hline
\end{tabular}

GBD = global burden of disease

${ }^{\text {a }}$ From [4]

In 1995, another report card was issued in the Journal of the American Medical Association [11]. This report card was an update on the progress and development of trauma systems since the 1988 report. It was a more sophisticated approach; it expanded the eight original trauma criteria and was more comprehensive. According to the 1995 report, five states (Florida, Maryland, Nevada, New York, and Oregon) had all the components necessary for a statewide system. Virginia no longer limited the number of designated trauma centers. An additional 15 states and Washington, DC, had most of the components of a trauma system.

Bazzoli upgraded her 1995 report card at the Salishan Conference in 1998 [12, 13]. There now are 38 states that are actively engaged in meeting trauma system criteria. Many of these states have implemented their systems through federal support of the Trauma Care Systems Planning and Development Act (Public Law 101-590).
Although there has been constant growth and development of statewide trauma systems, there still are underserved areas in the United States, particularly in the rural areas. This is unfortunate because one study has shown conclusively that a statewide trauma center makes a major difference in trauma outcome in rural areas once a trauma system has been established [14]. MacKenzie et al. [15] did a study in 2003 of a national inventory on trauma centers and mapped the locations of Level I and Level II centers (Fig. 3) and Level III and IV centers (Fig. 4). Finally, in 2006, a more definitive study evaluating the effect of trauma center care on mortality showed that the mortality from trauma was $7.6 \%$ in designated trauma centers compared with $9.5 \%$ in hospitals that were not designated trauma centers [16]. One year after discharge, the significance continued with a mortality of $10.4 \%$ vs. $13.8 \%$. This slight increase in the 1-year mortality most likely represents deaths in the elderly and late deaths from traumatic brain injury. Another study published in 2006 from Florida showed that in counties with a trauma center, the mean fatality rate was $50 \%$ less than in counties without a trauma center [17]. The effectiveness of a trauma center is irrefutable as shown by these two recent studies and the data from Germany.

The centerpiece for the Canadian trauma system is the 17 medical schools in the various provinces. Designation of trauma centers is up to the province, and in several instances there is more than one trauma center per major metropolitan area. Like the United States, Canada has some very rural areas, particularly the plains provinces of central
Fig. 3 Levels I and II trauma centers in the United States

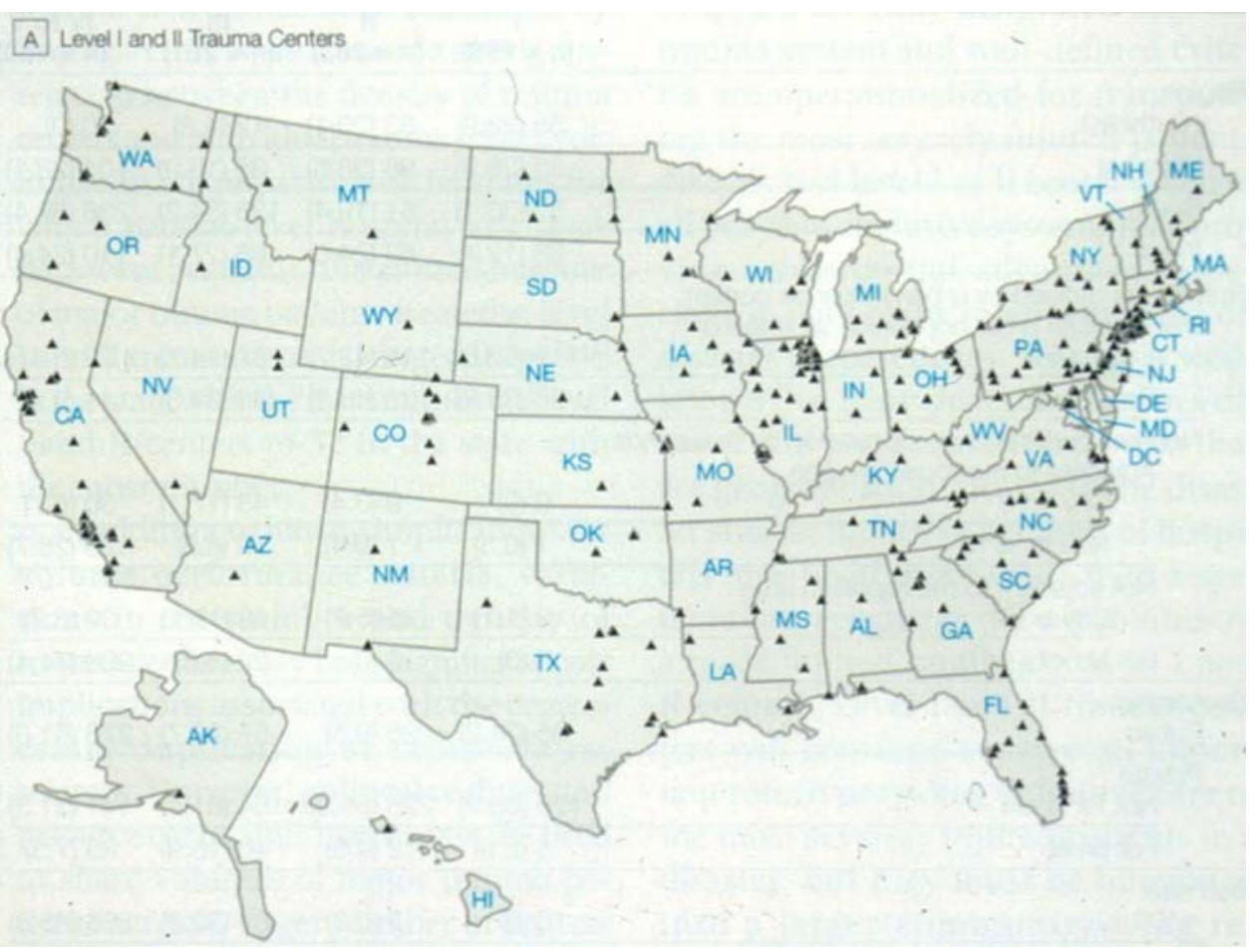


Fig. 4 Levels III and IV trauma centers in the United States

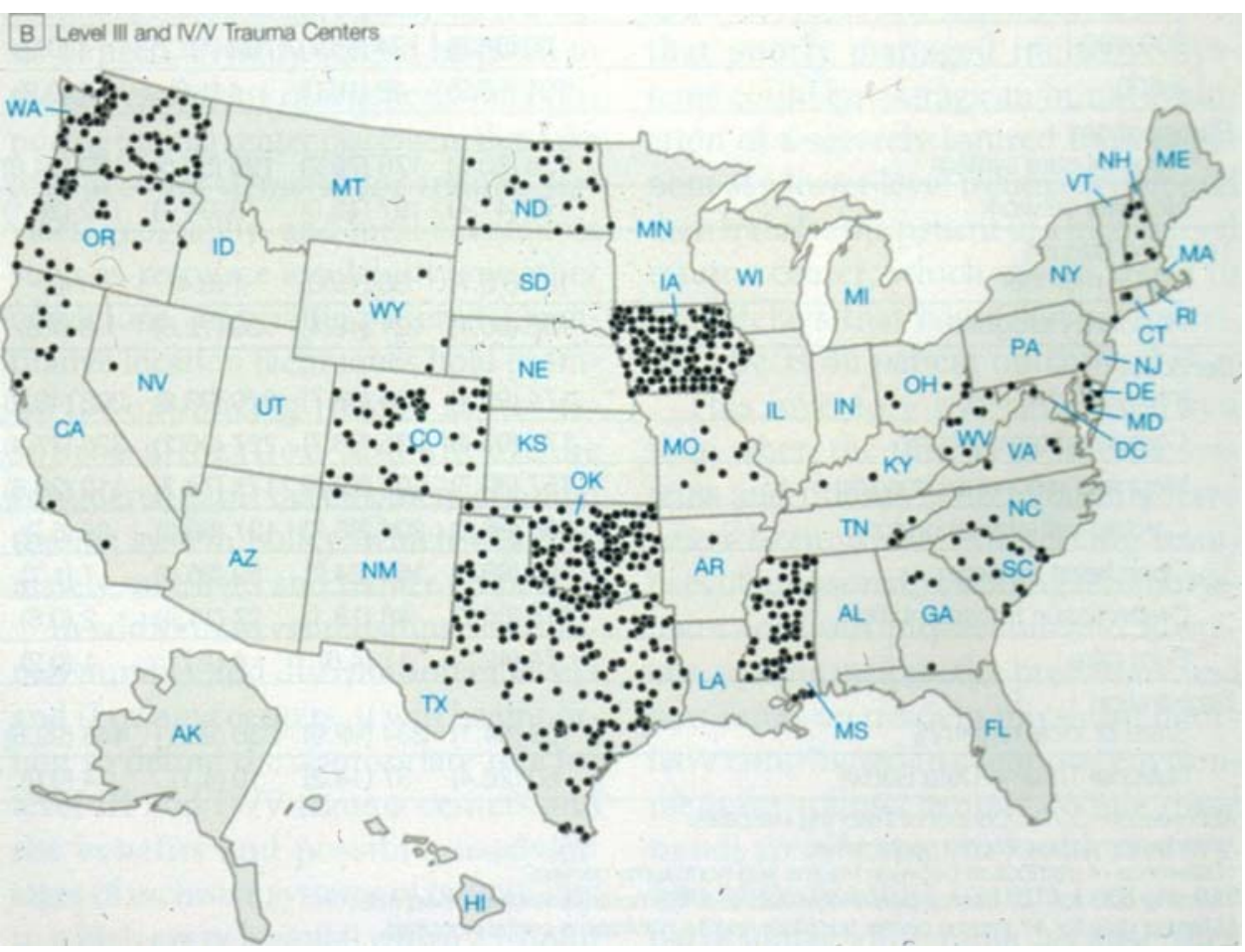

Canada and the Rocky Mountain West. Prehospital care in these regions can be prolonged despite common 911 and prehospital aircraft rescue systems. There have been some studies by Montreal's McGill University regarding prehospital care, not only in Montreal, but also extending from Quebec into Ontario [18, 19]. It was these studies that refuted the concept of trying to stabilize the patient at the scene and showed that physicians were not as effective as paramedics. Currently, there is no countrywide designation and verification process. Advanced Trauma Life Support (ATLS) is taught to almost all eligible physicians, and critical care is provided both by surgeons and physicians.

A study from Mexico shows that $96 \%$ of seriously injured patients are transported to hospital by ambulance [20]. Fifty percent of the prehospital personnel are volunteers with little or no training; the remaining half have basic emergency medical technician training. In a 1999 study, it was shown that some trauma centers in large cities focused on care of the injured [21]. Interestingly, only a few of the general surgeon attendants had taken ATLS, and essentially none of the residents had had ATLS. In [21], it was pointed out that the primary problem in having functional and designated trauma centers was the lack of funding and resource commitments. More recently, a study has been done comparing three areas within Mexico and trauma care delivery [22]. The authors used the World Health Organization's Guidelines for Essential Trauma Care as their guideline [23, 24]. The authors then did a study and evaluated by a "pre-review questionnaire" and a site visit process of these three areas. In total, five clinics, four small hospitals, and seven large hospitals were surveyed. The large hospitals averaged 1000-9000 trauma admissions annually. Using the World Health Organization criteria, they showed that resources were extremely limited in the small hospitals. For example, they lacked pulse oximetry. Large hospitals were fairly well supplied for acute resuscitation. However, most did report problems occasionally with blood supply. Using their study, which also looked at manpower, it was the intent of the investigators to show that the World Health Organization criteria are reasonable and that using them would allow various Mexican states to improve trauma care. The World Health Organization criteria are discussed in more detail later in this section; nevertheless, one of the shortcomings of the criteria is that the WHO lists specialists in tertiary care facilities in developing countries as "desirable" rather than "essential." Image intensification and angiography should also be "essential." It is noteworthy that they found that quality improvement was mandated by the Secretariat of Health for the larger hospitals. The quality of these programs was not studied in detail in this article [23, 24] and represents a departure from the verification visits conducted by the American College of Surgeons. The most positive thing about this study $[23,24]$ is that it shows that Mexico is addressing trauma as a serious public health problem, and physicians are addressing this from a systems standpoint, including human and equipment resources.

Costa Rica is a progressive country with respect to healthcare [25]. In 1942, the Caja Costarricense de Seguro Social (CCSS) was passed into law. This is essentially a 
social healthcare system that covers $87.6 \%$ of the population and consists of 23 hospitals with 5,861 beds. Trauma is the fourth leading cause of death in Costa Rica, with both general surgeons and orthopedic surgeons managing trauma patients. Because it is a social system, trauma care would optimally be provided in one of the larger hospitals, but there are problems in the rural areas' prehospital care and getting patients to these centers in a timely manner. Furthermore, there are only 154 general surgeons and 85 orthopedic surgeons in the country. In the 2002 article [25], it was admitted that surgical complications are difficult to analyze because statistics about the problem are underreported. A review of the literature does not catalog the number of surgeons who have taken ATLS and critical care is somewhat fragmented among medical, anesthesia, and surgical specialties.

South America represents a very heterogeneous mix of trauma systems and trauma care. One of the most violent areas in South America is Columbia. Trauma centers are present in Bogata, Medellín, Cali, and Cartagena. Violence is associated with drug trafficking and FARC (Revolutionary Armed Forces of Columbia), which terrorizes the eastern part of Columbia and contributes to the violence in the cities. Because of the differences in altitude and terrain, it is extremely difficult to provide ambulance services for some of the more rural and remote parts of Columbia. Even within major cities there is inconsistent ambulance service. At the present time, there is no statewide trauma system.

In a recent study from Brazil, emergency care was assessed for trauma patients [26]. This was a comparative study between two different periods: before and after the introduction of modifications in prehospital care. The emergency unit of the hospital of the University of Saõ Paulo is committed to trauma care. In addition to changing the prehospital system, it has also introduced ATLS. Despite these measures, the anticipated improvement in outcomes did not match that of the Major Trauma Outcome Study in North America. Nevertheless, it does show that with improvements in education and prehospital healthcare delivery, outcomes can be improved. Brazil is another country that has violence within the cities and a very large land mass with remote rural areas. There is no countrywide trauma system, and I believe it is fair to say that the universities within the major cities provide the bulk of trauma care. The same is true in Chile, where the economy has improved dramatically over the last 30 years. Excellent trauma care is provided in the larger cities, particularly Santiago; however, because of the geography of mountainous areas and a very long coastline, prehospital care is problematic.

In contrast to North America, the initial trauma care, resuscitation, and critical care in South America is not necessarily provided by general surgeons. Trauma surgeons are not recognized as a separate specialty except in Venezuela. Critical care is more often provided by adult intensivists trained in internal medicine. Many of the Latin American countries have also adopted Advanced Trauma Life Support, particularly in Argentina. They have also introduced Pre-Hospital Trauma Life Support.

Most of the countries in Latin American have embryonic or developing trauma systems, but the great majority of care is provided by university hospitals. In many instances, this is dependent on local leadership. In addition, the relatively new Pan American Trauma Society has fostered exchange of information and education between North America and South America.

The countries of Europe also represent a potpourri of trauma care and trauma systems. Böhler formed the first civilian trauma system in Austria in 1925. The Birmingham Accident Hospital was founded in 1941. It continued to provide regional trauma care until recently. A study done by the Royal College of Surgeons in England showed that the preventable death rate approached $33 \%$ of 514 patients with major trauma admitted to hospital accident and emergency departments [27]. As a consequence, an experimental trauma center was started in the Northwest Midland region [28]. The effectiveness of this regional trauma system, in essence, failed. Multiple critiques were offered in the British Medical Journal on the reasons for this failure, including data analysis [29-32]. It was also pointed out in letters to the editor that in Glasgow, where $16 \%$ of all major trauma are penetrating injuries, the results approach those obtained in the United States. Similar results have been presented from Edinburgh [33]. More recently, trauma centers have been started in the London area, but there is no state trauma system in Great Britain.

One of the better trauma systems in Europe is the one in Germany (Fig. 5) [34-36]. This system was established in 1975 and was based on the system that had been developed in Austria. This particular system has all four major components of acute care: prehospital care, resuscitation units, critical care units, and rehabilitation units. The results are remarkable. The mortality has decreased over $60 \%$ since the establishment of this statewide trauma system. Incorporation of East Germany into the German Republic has also shown an interesting comparison. The same decrease in mortality is now evident in the East German counties, despite an increase in the number of people injured because of increased use of automobiles. The German system also has a patient registry, and the patients are followed from the time of injury until resolution of their care through rehabilitation.

Another excellent system in Europe is that of The Netherlands [37]. This system is based on 12 trauma centers that are geographically distributed across the country with both Level I and Level II centers. They have also 


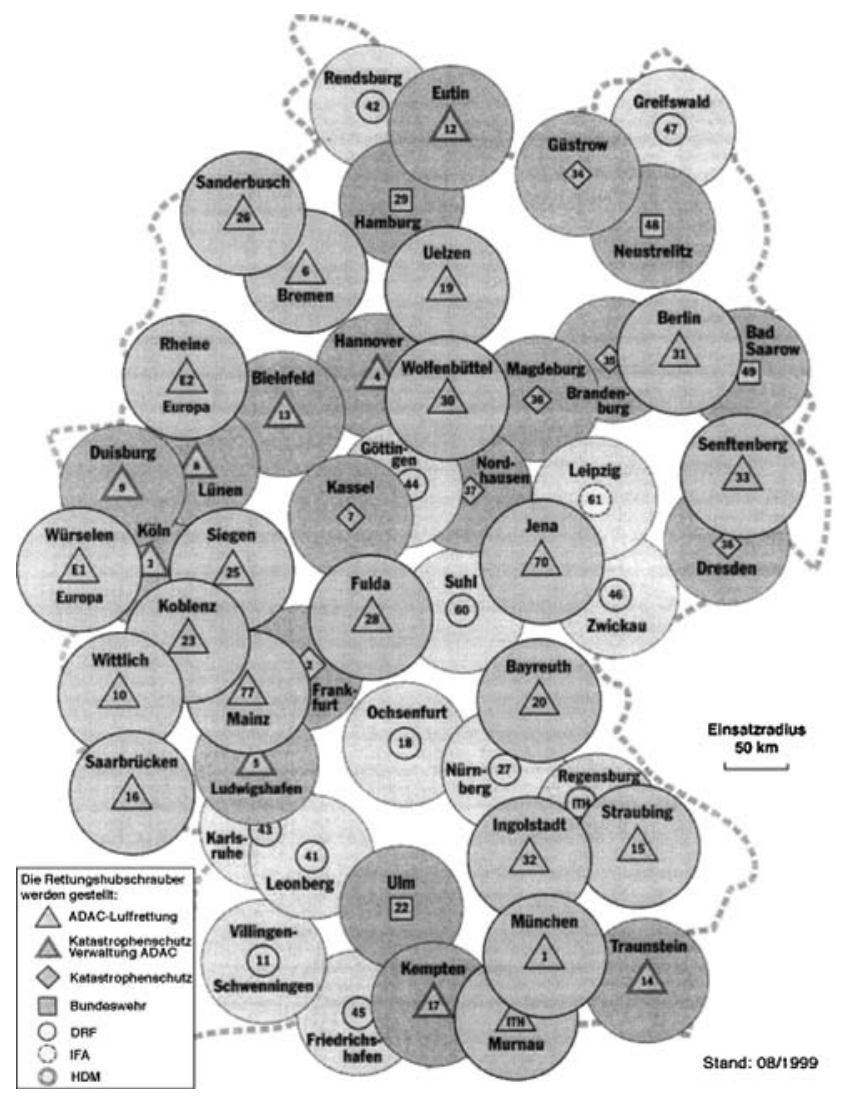

Fig. 5 The locations of helicopter rescue systems in Germany

focused on improvements in teaching, training (ATLS), regionalization of ambulance care, mobile medical teams, trauma helicopters, categorization and designation of trauma centers, and rehabilitation. Like many trauma systems, the Dutch system is imperfect, but the physicians are addressing the shortage of intensive care beds and establishing consistent and reasonable funding for their system.

Ari Leppäniemi has been a leader in studying trauma systems in Europe [38]. He points out that there are some major differences in how various countries have approached trauma as a public health and public policy problem. The French emergency system was developed primarily to respond to civilian, nontraumatic medical problems. In prehospital care there is a physician aboard the ambulance who attempts to stabilize the patient at the scene. This has not been a success with respect to trauma patients. The mortality within the French system is higher than in North America. A study done in Montreal, Canada, whose system was similar to that in France, showed that the prehospital outcomes were better when a paramedic transported the patient rapidly to the trauma center rather than try to stabilize the patient at the scene [18]. Leppäniemi also cataloged the various European countries with respect to what constitutes a trauma surgeon and the countries that lack state-mandated trauma systems. This has led to development of new systems in Sweden, Norway, Russia, Bosnia, and Herzegovina.

One of the major problems in Europe is that there is no concerted effort by the European Union (EU) to establish criteria for trauma systems or to coordinate trauma care between countries within the EU [39]. Similarly, the EU does not have standards for prehospital care, nor is there a network of rehabilitation facilities that have standards and are peer-reviewed. In theory, surgeons trained in one EU country should be able to cross into another EU country and practice surgery, including trauma care. Again, there is no standard for what constitutes a trauma surgeon, and, in fact, trauma surgery is a potpourri of different models [38]. One model is exemplified by Austria, where trauma surgery is an independent specialty. Another model incorporates trauma surgical training into general surgery; this is what exists in France, Italy, The Netherlands, and Turkey. A third model is where the majority of trauma training is part of orthopedic surgery residency training. This is true in Belgium [40] and Switzerland [41]. The largest model is where trauma surgery training is part of specific specialties without any single specialty having any major responsibility for trauma training; this is true in Denmark, Germany, Portugal, Estonia, Iceland, England, Norway, Finland, and Sweden. The differences in trauma systems, management, and education in Europe are highlighted in a report by Uranüs and Lennquist [42]. In their survey, they looked at trauma surgery as a specialty, helicopter transport, initial care of the patients, management in the emergency room, management in the hospital, and availability of rehabilitation facilities. Surgical specialists' responses were also surveyed.

Between the Maghreb of Northern Africa and South Africa is a large expanse of land with millions people and essentially primitive trauma care. This part of the world may be the most challenging in regard to future development of trauma systems and trauma care.

The largest cities in Northern Africa are Cairo (7.5 million), Casablanca (3.5 million), Algiers (3.2 million), Rabat (1.3 million), and Tunis (1.9 million). These cities also have universities and large hospitals that serve as trauma centers, but organized trauma systems are completely lacking, including prehospital care, particularly in remote areas [43]. In contrast, South Africa has seven wellestablished universities and several large hospitals in other metropolitan areas that serve essentially as Level I trauma centers. Their workload is extensive on a day-to-day basis because of the violence in this country. Resources to run these hospitals are increasingly difficult to obtain, and the system is susceptible to implosion. Rural trauma in South Africa is also problematic because of distances and allocation of resources. The land mass between South Africa and the Maghreb is essentially a developing part of the 
world where accidents, civil unrest, and civil war are a daily part of life.

Mock [44-46] has done extensive study on sub-Saharan Africa and the resources available for trauma care. Working with the World Health Organization, he has come up with Guidelines for Essential Trauma Care. The strength of the publication is that it sets forth 14 core essential trauma care services that can reasonably be provided to every injured person in every country. Modeled after the Optimal Criteria document of the American College of Surgeons, it looks at prehospital care, acute care, critical care, and rehabilitation possibilities in low-income and middleincome countries. In one of his studies, he looked at patients in Ghana with Injury Severity Scores greater than 9 who were transported for care within the city of Kumasi [47-49]. Fifty-eight percent arrived by taxi, $22 \%$ by private car, $7 \%$ by bus, $2 \%$ by police, and $11 \%$ by unspecified means. None were transported by ambulance. For patients who lived in rural areas 100 miles from Kumasi, it was found that only $41 \%$ arrived at the hospital within 24 hours of their injury, $44 \%$ between 1 and 7 days, and 15\% after 1 week. Similar data have been shown in Nigeria [50,51]. In Lagos, $55 \%$ of injured persons are transported in public vehicles, $35 \%$ are conveyed in private cars, and only $6 \%$ are moved in ambulances. Not surprisingly, less than $15 \%$ of the trauma patients seen in the Accident and Emergency Center of the Lagos University Teaching Hospital are critical emergencies. This suggests that the severely injured die at the scene of the accident.

South Africa has a population of 47 million, and although it has a relatively sophisticated medical system, it is currently being overwhelmed by trauma because of

Table 8 Annual trauma caseloads by province ${ }^{a}$

\begin{tabular}{lllc}
\hline Province & $\begin{array}{l}\text { No. of } \\
\text { facilities } \\
\text { supplying } \\
\text { caseloads }\end{array}$ & $\begin{array}{l}\text { No. of } \\
\text { reported } \\
\text { cases }\end{array}$ & $\begin{array}{l}\text { Mean No. of } \\
\text { cases per facility } \\
\text { (SE) }\end{array}$ \\
\hline Eastern Cape & $(1)$ & $(2)$ & $(3)$ \\
Free State & 21 & 150,705 & $4,567(1,321)$ \\
Gauteng & 18 & 79,626 & $3,619(1,181)$ \\
KwaZulu-Natal & 38 & 198.406 & $11,023(2,386)$ \\
Mpuma langa & 18 & 200,144 & $5,267(1,106)$ \\
Northern Cape & 15 & 41,759 & $2,320(376)$ \\
Northern & 22 & 50,414 & $3,361(996)$ \\
$\quad$ Province & & 52,112 & $2,369(1,058)$ \\
North West & 14 & 36,954 & $2,640(1,091)$ \\
Western Cape & 30 & 236,032 & $7,868(1,065)$ \\
All provinces & & $1,046,152$ & $4,742(284)$ \\
\hline
\end{tabular}

$\mathrm{SE}=$ standard error

${ }^{\text {a }}$ Modified from a table in [52] violence and increasing road traffic accidents. A recent study looked at the annual trauma caseloads by provinces and this is shown in Table 8 [52]. Minimum caseload per facility is greater than 2,300 and the maximum is 11,000 . These caseloads could clearly overwhelm prehospital, hospital, and any rehabilitation services available.

China and India are the two most populous nations of the world, yet trauma systems and trauma care are confined to very few communities, essentially the highly populated cities [53-55]. The farther one gets from a large city, the more sparse prehospital services are, as well as hospitals that specialize in trauma care. The same can be said for Indonesia and Southeast Asia. In many instances, it is the university hospitals in these countries that provide trauma care for the severely injured. Many of the patients in the rural areas simply do not make it to these centers.

Japan is a densely populated series of islands with a fairly advanced and sophisticated healthcare system [5658]. Again, the universities and large metropolitan hospitals serve as resources of care for the trauma patient. Prehospital care is excellent in most areas, and rehabilitation is an important component of care for the injured patient.

Australia also has a beginning trauma system that is countrywide. They have now designated and verified 12 trauma centers (Level I and Level II) and in the past have had a unique way of approaching rural prehospital care (Fig. 6). The flying doctor and flying surgeon programs were extremely innovative.

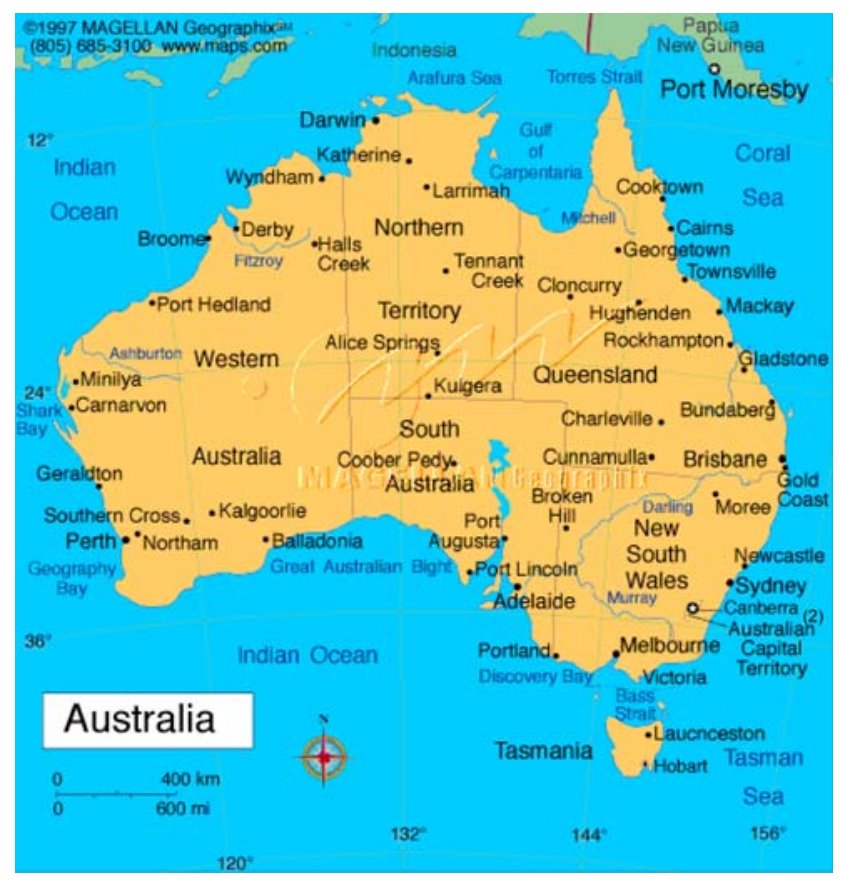

Fig. 6 Australia: Most of the population centers are along the eastern and southern coasts. Ninety percent of the country is rural or outback 
New Zealand consists of two long narrow islands with four population centers and two medical schools. There is no countrywide trauma system; however, the two universities provide excellent trauma care, as do Wellington and Christchurch.

As pointed out in the first section of this article, trauma care and war are inextricably linked. It would be inappropriate not to review the current issues facing the U.S. military when it comes to providing care for military troops in current "military actions" around the world [59]. These include Afghanistan (Operation Enduring Freedom) and Iraq (Operation Iraqi Freedom). We also have Special Forces and troops involved in the Philippines and subSaharan Africa. Approximately 30 years ago, the Department of Defense (DOD) adopted a "total force" policy, which occurred at a time when there was a transition to an all-volunteer active duty military force [60]. As part of this planning process, there were a number of force structure plans that looked at manpower and the need to simultaneously engage in two major regional conflicts (MRCs). The Army has its input through Total Army Analysis (TAA), and the penultimate TAA has been criticized by the General Accounting Office (GAO) in that there are not enough active duty and reserve components to meet a first MRC in a timely way. This is certainly highlighted by the current problems in Iraq and President Bush's decision to surge new forces into theater. This will overextend the active duty forces such that it is now doubtful we should even consider a second MRC. Forces needed for an MRC would arrive late and insufficient reserve components cannot make this up in a timely way.

Since Desert Storm there have been more problems identified in military medicine. There were several reports from the GAO that documented problems with medical shortage and medical capability [61-65]. The four general categories outlined by the GAO report were mobilization and deployment of medical personnel, problems with medical supplies, doctrinal employment of hospitals, and problems with patient evaluations and regulations. The GAO reports documented that many personnel were either incompletely trained or untrained for wartime missions. The GAO found that air evacuation support during Desert Storm was neither adequate nor responsive, particularly at night. This difficulty with the evacuation system extended into evacuation from theater. There appeared to be contention between the services regarding roles, responsibility, and equipment. The end result was a poorly responsive system. Finally, there were two other problems that occurred during Desert Storm that ran contrary to previous conflicts: there was no in-theater research and there were no civilian surgeons appointed as consultants to monitor healthcare in theater.

After September 11, 2001, even more demands and challenges were placed on the military in providing medical support, disaster medical planning, and fighting terrorism. This led the Army in 2002 to come up with TAA09, which defines the army force structure requirement, including Homeland Security, deterrence of aggressor, major combat operations, and small-scale contingency. Using all volunteer active duty medical resources and reserve makes it almost impossible to provide medical support for all of these requirements and still try to maintain the two-MRC requirements.

After the adverse reports on Desert Storm from the GAO, the DOD did make some changes to address combat care capability [66]. Military attending surgeons and residents can now train in several civilian trauma centers. In addition, a few military academic centers are caring for civilian trauma injuries. Problems have been identified. We do not have an evaluation of the effectiveness of civilian trauma training for military personnel. The experience is not continuous, and we do not know whether exposure on an ad hoc basis is consistent with maintaining skills and experiences. In those few military academic health centers that care for injured patients, there has been one failure to meet American College of Surgeons verification standards.

In theory, reserve units are a major resource for medical and nursing personnel in combat or conflict. Reserve unit trauma training is essentially nonexistent. An additional demand for medical personnel, particularly surgeons, is the Disaster Medical Assistance Teams (DMATs) currently under the Department of Health and Human Services. They are supposed to respond to civilian disaster, either secondary to natural events or terrorism. Surgeons, anesthesiologists, and nurses may or may not have continuous trauma experience in their civilian jobs. How do we maintain trauma experience and skills in active duty reserve and DMATs? An option is to support the concept that all military academic health centers should be actively involved in caring for civilian trauma injuries. This would maintain skills for those surgeons, anesthesiologists, and nursing personnel that treat trauma patients on a continuous basis. DOD has had an opportunity to implement such a program but has failed to do so.

DOD has not addressed training of reserve personnel in trauma care. We do not even have requirements or normative standards that define what our expectations are for a nurse or surgeon in a reserve unit who may be activated to treat a trauma patient.

\section{Discussion: what needs to be done}

To anticipate what is needed for the future management of trauma care and development of trauma systems, we must return to the Burden of Disease Study by Murray and Lopez [4]. They have projected that on a worldwide basis by 2020 
road traffic accidents will be the number three cause of disability adjusted life years (DALYs). War injuries will be the number eight cause of DALYs. In developed regions, road traffic accidents will be number five and selfinflicted injuries will be the number 10 cause of DALYs. In developing regions of the world, such as sub-Saharan Africa, road traffic accidents will be the number two and war injuries will be the number eight cause of DALYs. If one examines the ten leading causes of death in 2020 worldwide, road traffic accidents will be the number five cause and self-inflicted injuries will be number nine cause. In the developed regions of the world, self-inflicted injuries will be the number eight cause of death and road traffic accidents number nine. In the developing regions of the world, road traffic accidents will be the number four cause of death (Tables 9 and 10).

In discussing what needs to be done, I will continue to use the model developed by Murray and Lopez and break down the world into two parts: the developed and developing. I believe it is fair to say, with few exceptions, that the developed world has an imperfect system of trauma care. It has been reported that $44 \%$ of patients in most states in the U.S. do not have access to a trauma system or trauma care (Level I or Level II) [67]. Many states are not willing to provide the resources necessary to have a system or to complete it. I have previously commented that our national healthcare system is dysfunctional and contributes problematically to a cohesive and complete development of a nationwide trauma system (Tables 11 and 12) [3]. There are other fundamental problems, including work force shortages and even lack of some health resources. In 2002, Cooper et al. [68] published an article on physician supply. He predicted that there would be a shortage of physicians that would not be relieved by physician extenders, including nurse practitioners and physicians' assistants. A follow-up article in 2004 stated that by 2020 the deficit would be as great as 200,000 physicians, primarily specialists, particularly in the surgical fields, but also in gastroenterology and cardiology [69]. This shortage will have a profound negative effect in several areas, including rural surgery, military surgery, and care for the elderly, and as noted in the American College of Surgeons' White Paper, it is already a major problem in trauma and emergency surgery [3]. The Cooper et al. work does not take into consideration that one-fourth of all physicians in the United States are currently international medical graduates.

The shortage of trauma surgeons exists now and will be worse in 2010 when the baby boomers begin to reach age 65 . The average age of a general surgeon in the United States is 52 years. Recently, there had been a decline in the number of applicants to general surgery programs, and this was further affected by gender (Figs. 7 and 8) [70]. At

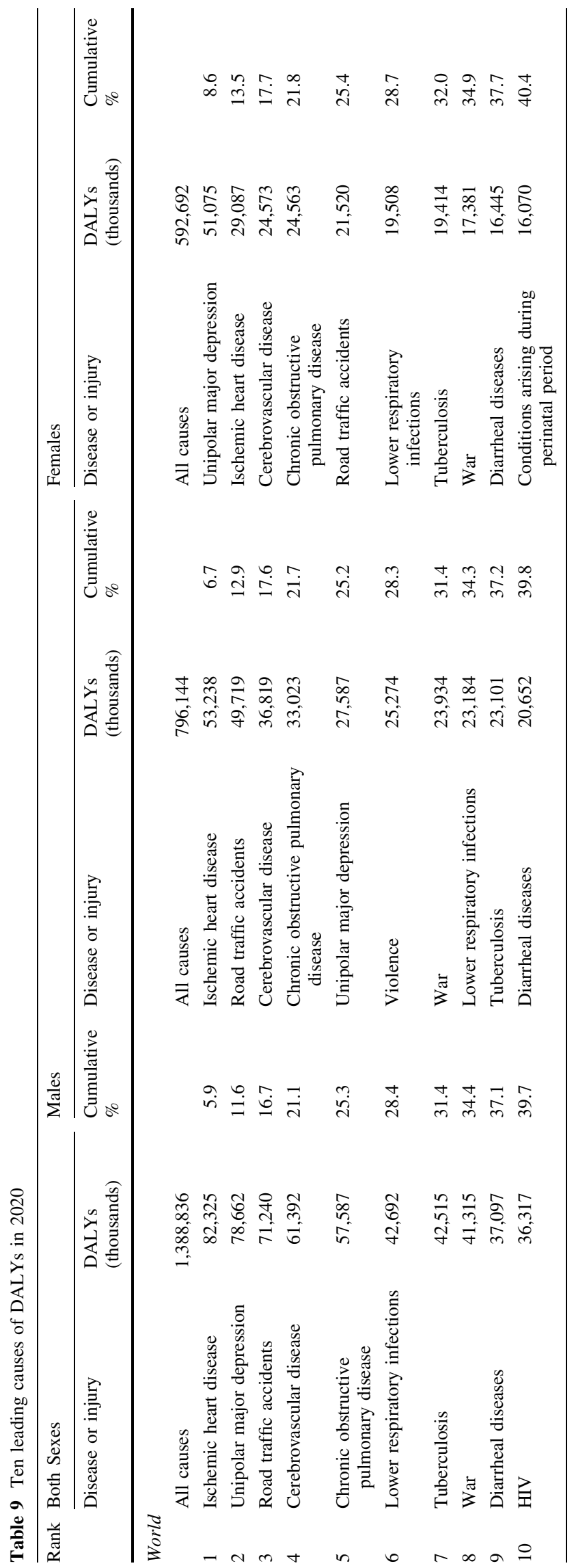









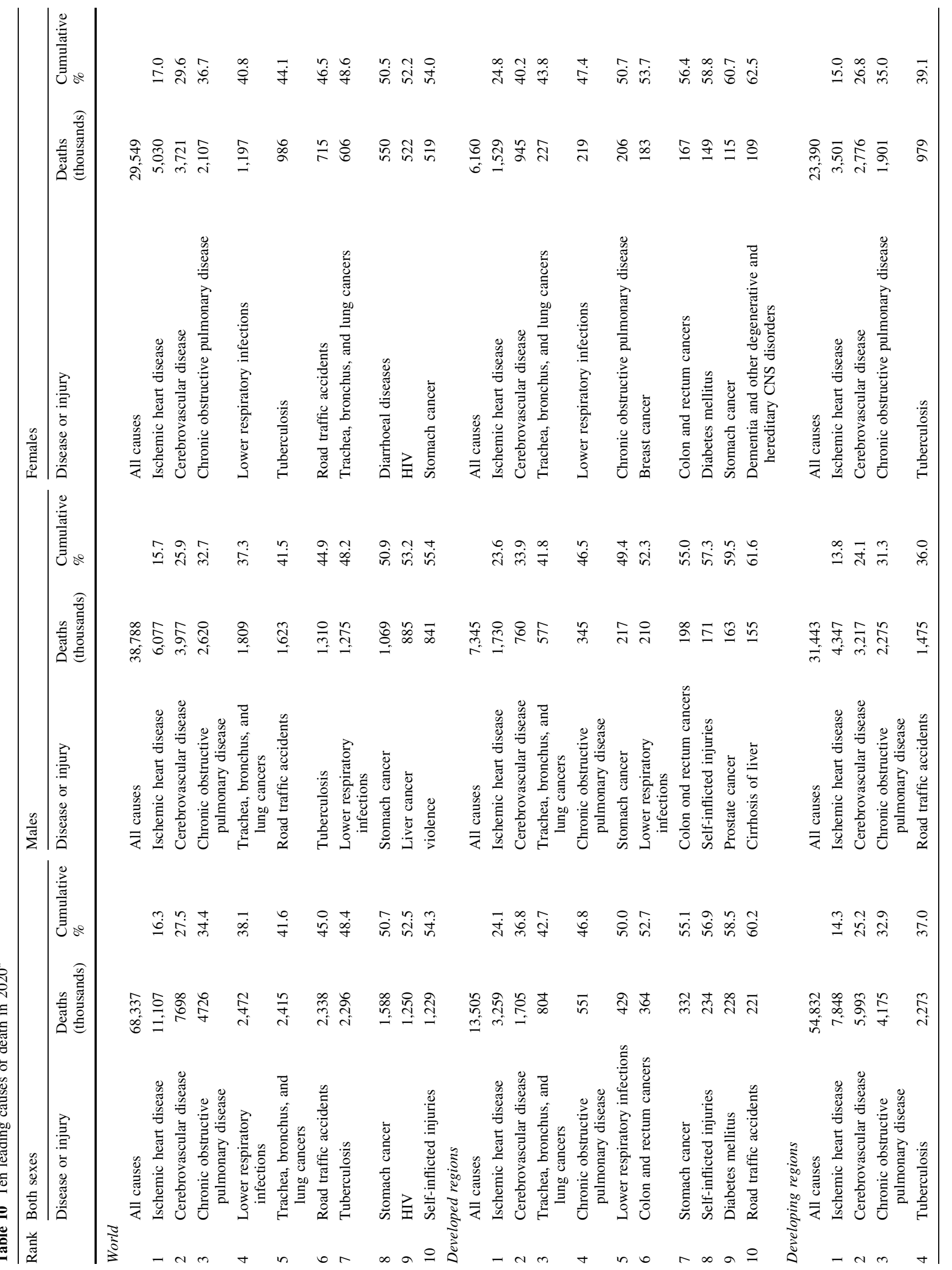




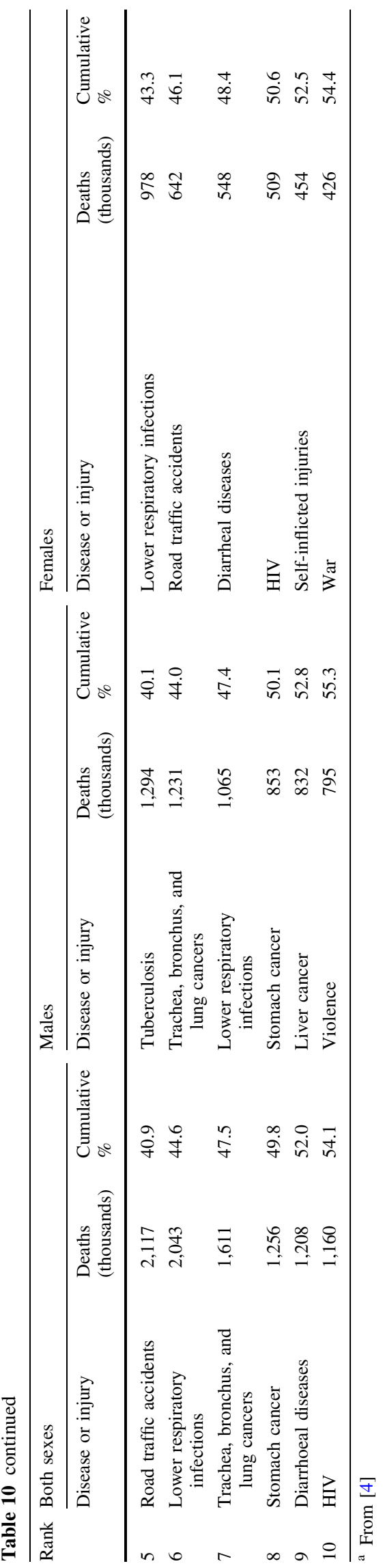

Table 11 Current US healthcare ${ }^{\mathrm{a}}$

- The system is broken

- A system that was largely "not-for-profit" has become "for-profit"

- Forty-seven million have no insurance

- Tens of millions are underinsured

- Annual cost is now \$2 trillion

- Cost is $\$ 7026 /$ person

${ }^{a}$ From [4]

Table 12 Current challenges-United States

Dysfunctional healthcare system

Rural surgery

General surgery

Military surgery

Disaster medicine

Trauma surgery

Nurses shortage

least $50 \%$ of graduating medical students are female but very few apply to general surgery ( $7 \%$ or a little more than 500 applicants). Part of this disinterest in general surgery seems to be the hours required, part of it is lifestyle, and part of it is a desire to combine a professional career with the traditional role of parent; it also reflects that the general surgery programs have not provided a structure whereby surgical residents can do both. Recently, this has changed and women are now applying to general surgery in increasing numbers.

In addition, general surgery continues to become more fragmented and specialized, but the general surgery specialists have one thing in common: they do not want to take a rauma call. In a 1990 study, Esposito et al. [71]

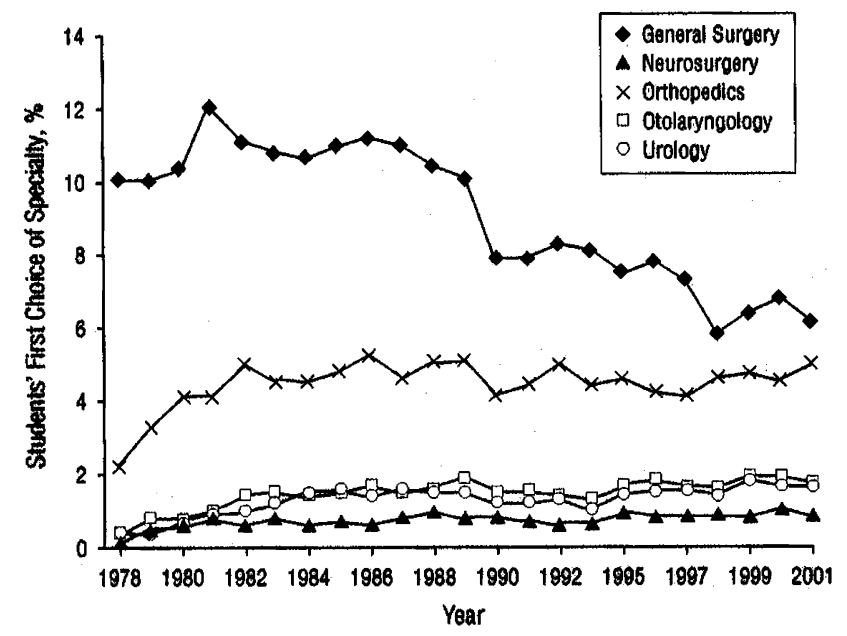

Fig. 7 General surgery is declining in appeal to medical students: Orthopedics has increased slightly, and other surgical specialties tend to be flat [with permission from [70]] 


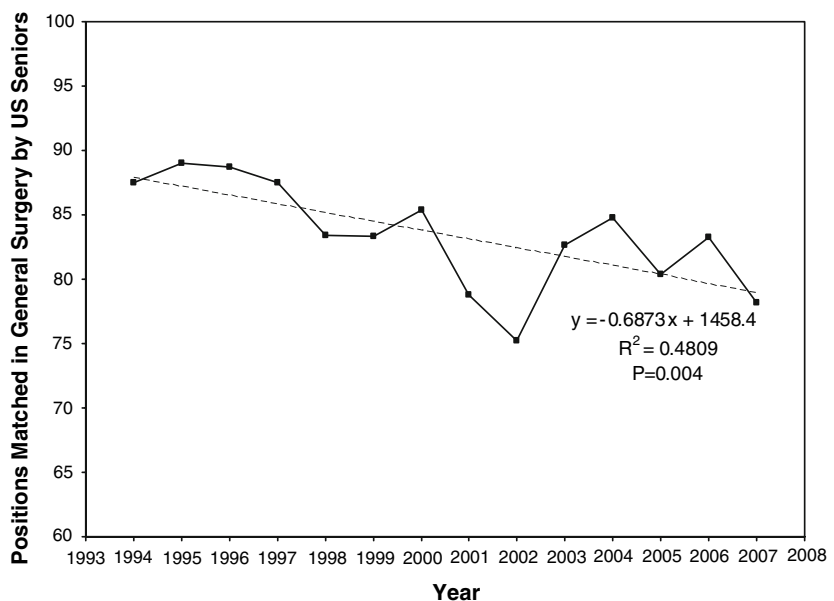

Fig. 8 Positions match students in general surgery (from National Resident Matching Program)

polled all surgeons in Washington State about treating trauma patients (response rate of 50\%). The top four factors influencing the decision not to treat trauma patients were time commitment, compensation, dissimilar reimbursement, and a perceived increased medical/legal risk. Similar findings were found in the American College of Surgeons' White Paper [3]. The report indicated that surgeons are taking calls five to ten times a month; they may do this at two or more hospitals, and the hospital bylaws, which typically require surgeons to participate in on-call panels, may allow surgeons to opt out. There was a perception by surgeons that they were being sued by patients who were first seen in the Emergency Department.

It is important to emphasize that the growing crisis in patient access to emergency surgical care exists now. In 2002, the Lewin Group, in a study for the American Hospital Association, showed there is a nonavailability of neurosurgeons, orthopedic surgeons, general surgeons, and plastic surgeons to cover emergency department on-call panels [3]. This was further emphasized by the Schumacher Group and two similar surveys carried out by the American College of Emergency Physicians in 2005. In that particular study they showed that nearly three-fourths of emergency department medical directors believe they have inadequate on-call specialist coverage, which was an increase over 2004. The surgeons involved include orthopedic surgeons, plastic surgeons, neurosurgeons, otolaryngologists, and hand surgeons. This is compounded by the flat or decreasing rate of general surgeons who are completing training, as well as neurosurgeons. Orthopedic surgeons have slightly increased the number of residents admitted to their programs.

A problem that is not mentioned in the White Paper is that specialty surgeons and general surgeons are increasingly asking for exorbitant on-call pay. These monetary

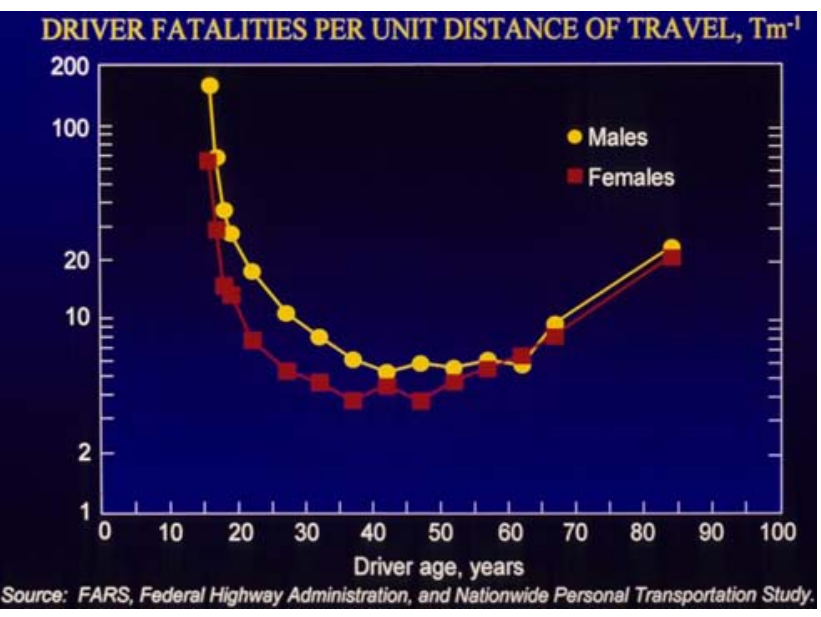

Fig. 9 Relationship of death to age, gender, and distance of travel

requests range anywhere from $\$ 1000 /$ night to more than $\$ 7000$ in some of the subspecialties such as neurosurgery.

A major problem by 2010 will be the $30 \%$ increase in the elderly population. It used to be that the peak in death rate from injury was in the age range of 16-24 years. We are now seeing a bimodal distribution, with an increased death rate in the elderly (Fig. 9). They are more active and unfortunately the mortality rate for an Injury Severity Score $>15$ is 3.5 times higher than the rate for their younger counterparts. They spend more time in the intensive care unit and do not have a good return to independent living status or quality of life after acute trauma care [72].

The lack of general surgeons also negatively affects the DOD and its need for surgeons. Approximately $20 \%$ of DOD surgeons are active duty surgeons; $80 \%$ must come from the reserves. Unfortunately, young surgeons do not join the reserves. Studies conducted by the GAO after Desert Storm show that surgeons were not being trained properly for trauma, particularly active duty surgeons (however, the DOD, as mentioned earlier, has recently improved this over the last four years). One solution is for DOD and Health and Human Services, working with Homeland Security, to increase by one-third the surgical, anesthesia, and nursing personnel in American College of Surgeons verified Level I and II trauma centers. These individuals would then belong to a reserve unit and serve as a reserve manpower pool. They would be subject to instant call-ups for either DOD, DMAT, or Homeland Security needs. This would be similar to pilots who fly commercial jets and belong to reserve units and can be called to active duty. The Netherlands has been doing this for approximately 10 years and it works well for them. Another solution would be to encourage surgeons, anesthesiologists, and nurses to join military reserve units. Cancellation of medical school debts might be an incentive. Conscription is 
highly unlikely considering to current attitude in Congress; however, renewal of a "Berry-Plan" program might be possible. Somehow, we have to convince surgeons, anesthesiologists, and nurses that if our government commits to a war, a small-scale contingency operation, or antiterrorism activities and our soldiers are placed in harm's way, they deserve the very best combat care possible. Objection to these governmental actions on a political basis should not be a consideration for medical and nursing personnel.

Another negative impact on trauma care is that many trauma centers are closing or downgrading their level of care. Since 2003, "dumping" has become an increasing problem for Level I and II trauma centers. EMTALA (Emergency Medical Treatment and Active Labor Act), which was originally designed to prevent "dumping," now actually contributes to it. This phenomenon is characterized by a community hospital ER physician calling the trauma center and speaking to an emergency physician or surgeon because they have a trauma case that they "cannot provide care for" either because of lack of personnel or the patient's case is too complex. Many of these patients reach the trauma center; they are observed and then discharged the following morning.

Another major problem in trauma care is that rehabilitation beds are not available after a severe injury. The GAO did a study showing that only one in eight patients with traumatic brain injury received appropriate rehabilitation following their acute care [73]. Rehabilitation is particularly a problem in patients who have no insurance.

A particularly vexing problem is the importation of physicians and nurses to the United States. In many ways, this confirms the premise of Friedman's book The World is Flat [1]. As noted earlier, the United States is already outsourcing pharmaceuticals, and we even outsource some surgical procedures. We have been importing healthcare professionals for many years - primarily nurses, but more recently physicians and surgeons. To fill general surgery training slots, $18-23 \%$ are being filled by foreign medical graduates. This is a pitfall to a "world is flat" model. Most importantly, this involves a "brain drain" from the developing countries that need these physicians most.

Another problem of importing surgeons from developing countries is that the only test they must pass is the U.S. Licensing Medical Examination. This exam does not include knowledge or psychomotor skills related directly to surgery. Knowledge tests could be developed that would be similar to those that the American Board of Surgery administers, and psychomotor skills could be tested with virtual simulators. However, virtual simulators are quite expensive. Many of these imported surgeons could go to rural hospitals and be credentialed by hospital medical staff. This not only reflects the shortage of general surgeons in rural areas, but also highlights the need for competency testing. Probably the biggest disadvantage of "the world is flat" approach is that it is a short-term solution. It does not ensure a steady output of nurses, physicians, and/or specialists in the U.S. For example, by 2020 , the U.S. will be short 800,000 nurses. At the present time, 140,000 applicants to U.S. nursing schools are turned down each year because there are not enough positions due to a lack of nursing instructors. Importing nurses is not the answer.

Another vexing issue is one of gender. At the present time, female medical students have not been attracted to the field of surgery. This is potentially the largest pool of talented individuals that could help solve the shortage of general surgeons. To attract women into the specialty, we will have to solve lifestyle issues, such as protected time, both during training and during their practice. At the University of Melbourne in Australia, female residents are given extra time to finish their surgical training. Emergency medicine has increasingly become an attractive career choice for women because they can do shift work. The concept of the emergency general surgeon who would do trauma and emergency surgery is most likely going to be accomplished by full-time surgeons who do shift work in acute care hospitals. Based on a 40-hour work week, full-time surgeons work approximately 160 hours a month. To assign 12 or 13 shifts of 12 hours each would come close to this, which means that within a 2-week period, a surgeon could fulfill his or her workload and have the next two weeks off. (There are obviously many variations of this model.) This is precisely what occurs in emergency medicine. Hospitals could participate by providing 24-hour childcare for physicians and nurses. There are probably few perks that would be more attractive from the standpoint of maintaining a professional career while being a parent.

Canada is rich in resources. It is difficult to understand why it has not moved toward a nationwide trauma system. The central plains and mountainous west coast do have a problem with remote frontier and rural prehospital care. I think that most economists would consider Mexico a middle-income developing country. It is quite probable that over the next 10-15 years, as their economy improves, so will the trauma system across the country. Costa Rica, with its excellent commitment to healthcare for all citizens, could easily have a nationwide trauma system. Other countries within Central America and South America will have a mixed solution to statewide trauma systems. This will partly depend on natural resources and the economy, but the need is extreme in some areas with increased violence, such as Colombia and Brazil. It will also depend on how stable the government is and the degree of corruption. The Pan American Trauma Association could apply the "Essentials" of the World Health Organization to the various countries and determine what optimal criteria each 
country could reach most easily. These essentials would be updated on a regular basis, and as the economies improve, trauma should be a high priority and reflect the additional resources.

The solutions in Europe will be somewhat problematic. I believe it is safe to say that there are no overall standards agreed upon in the European Union to address optimal prehospital care. The Royal College of Surgeons of Edinburgh has a faculty of Pre-Hospital Care, which is setting the standards and verifying it by a peer review process. These could easily be applied across the European Union, but at this time there is no concerted effort to do so. I think it is also safe to say that medical education, and specifically surgical training, varies markedly from country to country. The same could be said for who does critical care and what the standards are. The current approach to training a trauma surgeon in the EU varies and different specialists tend to provide this. This is not necessarily bad, but there should be some standards that constitute the bare minimum in order for surgeons to go into other countries of the EU and practice within this standard of care. Rehabilitation within Europe is also variable. One of the best examples of an excellent trauma rehabilitation program exists in Israel. This might represent a model for the EU. The best place to start would be for the EU to develop a document similar to the American College of Surgeons' Optimal Criteria that would apply to all countries. It cannot be overemphasized that all three components of a trauma system (prehospital, acute care, and rehabilitation) must have some type of review and verification.

Eastern Europe represents a challenge in development of trauma care and trauma systems. Western Turkey is well on its way to having an excellent trauma system; however, eastern Turkey has yet to benefit from such planning and resources. As the economies in the Balkan states improve, it is inevitable that trauma systems will develop, but not necessarily at the same rate in the various countries. With the collapse of the former Soviet Union, the European portion of Russia has more resources but there is no statewide system of trauma care [74]. The Asian portion of the former Soviet Union is quite problematic because of the huge distances and sparse resources. Again, it would be very worthwhile to implement the Pre-hospital Trauma Care Systems and Guidelines for Essential Trauma Care that have been developed by the World Health Organization.

Japan evaluated in 2002 whether they had preventable deaths. It was shown that about $40 \%$ of trauma patient deaths were preventable. This led to the development of Japan Pre-hospital Evaluation and Care Program and the Japan Advanced Trauma Evaluation and Care Program for Physicians. A trauma registry has been started, and the process of designating a trauma care hospital is well on its way.
China is not only growing economically, it also addressing healthcare. China has four military hospitals in Shanghai, Beijing, Guangzhou, and Chongqing that serve the military and their families. What is lacking is a system of trauma care for a population of 1.3 billion people. The boom in the economy is leading to increased automobile use and the predictable increase in automobile accidents. Industrial accidents are also increasing. Fortunately, the boom in the economy has led to a significant surplus in government funds. Hopefully, some of this money will be spent on development of prehospital, hospital, and rehabilitation facilities that will serve a very large land mass. They have already developed a " 120 " emergency medical service system, but it covers less than half of the population.

Hong Kong has a more developed system of trauma care [75]. This is a city of 6.4 million in a total area of $1100 \mathrm{~km}^{2}$. They have a fairly sophisticated prehospital system and he ambulance attendants were trained to the first aid standard of the St. John First Aid Manual of the United Kingdom. More recently, they have advanced this training to an EMA-II modeled after British Columbia, Canada. Trauma management is essentially basic trauma life support. They have 33 ambulances and 173 ambulance personnel. In addition to the prehospital care, they have a hospital authority with 14 accident and emergency departments. There are 11 major acute care hospitals, but only eight have neurosurgeons in attendance. The two large university hospitals, Queen Mary Hospital (The University of Hong Kong) and Chinese University Hospital are Level I facilities. In addition, there is an American College of Surgeons Hong Kong Chapter that provides ATLS courses. Over 180 doctors have attended this course. Rehabilitation exists in a number of centers.

Unfortunately, India lacks an organized trauma care system, and has been characterized as being in a "nascent stage" [76]. It is agreed that about $10.1 \%$ of all deaths in India are due to accidents and injuries. Prehospital care is described as "virtually nonexistent in most rural and semiurban areas." There is no minimal education and training standards for paramedics. Acute trauma care is offered by some government hospitals, corporate hospitals, and small clinics. University hospitals provide a reasonable level of care, but this is not universal. Of the 205 medical schools, 20 are private, and $60 \%$ of the state-run medical schools have deficiencies in infrastructure, facilities, and faculty [77]. On the positive side, India is in a major economic boom and, by using the WHO Guidelines, could easily establish the essentials for both prehospital and acute care facilities.

In Thailand, the number of trauma-related deaths has dramatically increased and are second only to deaths from heart disease. An effort is being made to improve care within the various provinces and to provide high-quality 
EMS and trauma care, but this is not consistent across the country [78].

Malaysia, a country of 20 million people, is also addressing trauma care and trauma systems [79]. Prehospital care lacks cohesiveness; in many instances, tow car operators often transport the injured to hospital, and not necessarily to one with trauma care resources. This is particularly true in rural areas. Trauma care in the large university hospitals in the heavily populated areas such as Kuala Lampur is quite good, but the farther one gets from a large metropolitan area, the more problematic it becomes. Rehabilitation centers are few, and patients with traumatic brain injury and spinal cord injury suffer as a consequence. Most of the resources are in Peninsula Malaysia.

Indonesia has a significant problem with trauma system development because of the multiple islands ( $>18,000)$. Indonesia is on a very active tectonic plate and is prone to natural disasters. In addition, there have been a number of terrorist acts. The Asian Surgeons Association is active in trying to establish a "118" Emergency Ambulance Service and develop a prehospital emergency medical service. They are in the embryonic stage at this point. Trauma care, even in the large urban areas, can also be problematic because of a lack of ambulances and resources to care for road traffic accidents and to deal with the ongoing violence, particularly terrorism. The World Health Organization Essentials of Pre-hospital Care and Pre-hospital Systems would be a reasonable guide to use in prehospital and trauma care facilities.

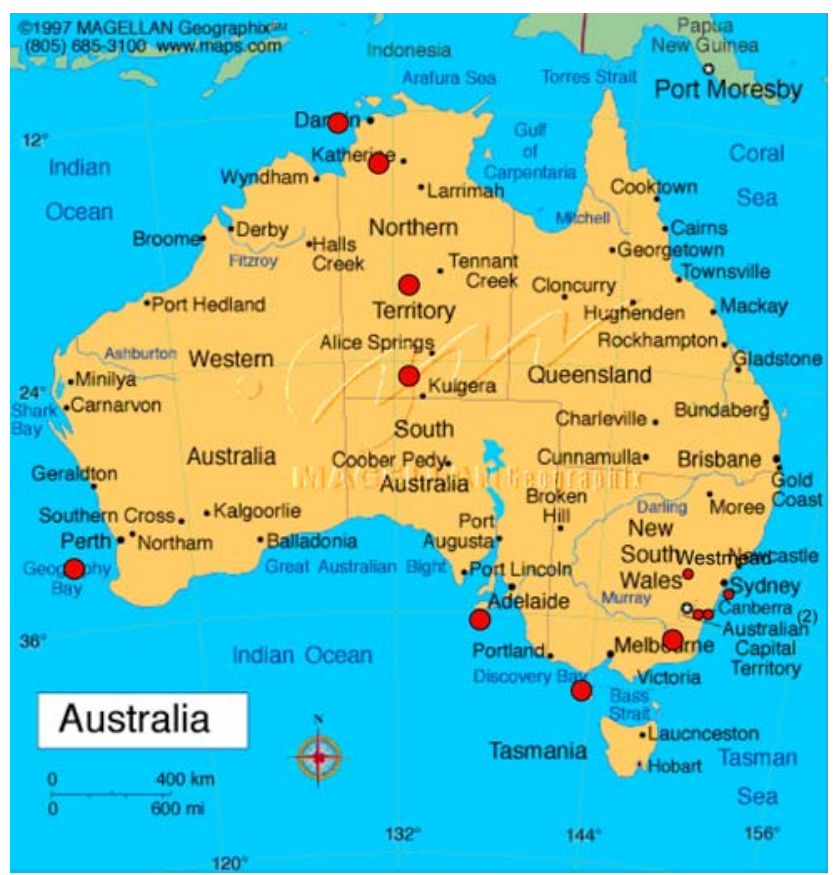

Fig. 10 Current location of Levels I and II trauma centers (from Royal Australasian College of Surgeons)
Australia is well on its way to having a nationwide trauma system (Fig. 10). New Zealand has yet to systemize their prehospital and acute trauma care. New Zealand has two large university hospitals that provide Level I care. There are also a number of institutions that could provide either Level I community care or, more probably, Level II care. There are rehabilitation units. Prehospital care is a problem for very remote areas and the very long islands with their long coastlines and mountains.

The last area to be discussed is Africa. The Northern Crescent of Africa is problematic from the standpoint of getting the various countries to cooperate and come up with a system of trauma care that transcends borders. Many of these countries are attractive to tourists and some have natural resources that add to their economy. Violence and terrorism are a problem. As noted earlier, the university hospitals serve as a focus for trauma care, but in the rural areas, problems exist with prehospital transport and transfer to higher centers of care. Rehabilitation is disjointed and in many instances inadequate. South Africa has a trauma system; however, it borders on being overwhelmed [80].

Between the Northern Crescent and South Africa is subSaharan Africa. Almost all of these countries would qualify as low-income developing countries. There is no area on earth that exemplifies the problems of healthcare and the concept that Friedman extols in The World is Flat. Billions of dollars have been poured into sub-Saharan Africa over the last few years. For example, the Bill and Melinda Gates Foundation has given $\$ 6.6$ billion to global health programs, most of which went to Africa. The United States has increased its overseas development assistance to $\$ 27.5$ billion in 2005 . One would think that this would lead to better healthcare, but this has been challenged. Laurie Garrett, writing in Foreign Affairs, makes a very persuasive argument that this money may actually be harmful [81]. She argues that the money is paying for largely uncoordinated efforts and directed mostly at specific, highprofile diseases rather than at public health in general. She also argues that aid is tied to short-term numerical targets and is not being used to develop a sustained healthcare system. She points out that there are no built-in methods of assessing efficacy or sustained ability of many of these programs. The situation is compounded further by corrupt governments that siphon away up to $80 \%$ of the dollars intended for healthcare projects. A typical example is Ghana. In 2006, the World Bank reported that about half of all funds donated for health efforts in sub-Saharan Africa never reached the clinics and hospitals at the end of the line. There is another problem, called "stove-piping," where money goes through narrow channels that relate to a particular program or disease, mostly infectious diseases, and very little money is left for problems such as trauma. 
Another problem is that the nongovernment organizations involved in some of these healthcare programs in subSaharan Africa are actually c making the problems worse. They often try to recruit doctors and nurses to come back from developed countries. In Ghana, of 871 medical officers, 604 have left the country and now practice overseas. Similarly, in Zimbabwe, 1200 doctors were trained in the 1990 s, but only 360 remain in the country today. In Zambia, 50 of the 600 doctors trained over the last 40 years remain. Kenya has lost 1670 physicians and 3900 nurses to emigration. Garrett argues that preventing the "brain drain" by increasing the salaries would be enormously expensive and might not even work.

The answer to the above problem seems somewhat straightforward. At the present time, global health improvement is being funded at $\$ 20$ billion annually. This money cannot go just for pet projects, such as HIV, tuberculosis, and malaria. Some, if not most, of this money should go to build the infrastructure for a public health system, including ambulances, clinics, and hospitals. Obviously, I would push for a system of trauma care. Such a solution would probably not cost that much more in dollars on an annual basis, particularly if one could control the corruption and waste. Using the World Health Organization Guidelines, sub-Saharan Africa could very well solve its trauma problems. In addition, communication would have to be addressed. Although there is a designated 999 number for emergencies, rural areas have almost no access to phone communication or even radio communication. Similar to Europe, there should be an organization within the various African countries that could establish triage criteria that would transcend national borders. All physicians should be encouraged to be trained in ATLS. Professional organizations could push the various national governments to make training a priority and to establish criteria based on the World Health Organization's essentials that all countries should meet. Surgeons from Europe could help sub-Saharan Africa in multiple ways. Providing instructors for the ATLS course is one example. The Definitive Trauma Surgery Course and the American equivalent ATOM would be very useful to practicing surgeons in these developing countries. The World Health Organization and/or companies that make surgical instruments or pharmaceutical companies could provide grants to teach these courses throughout sub-Saharan Africa. Trauma programs in the United States have multiple trauma and critical care fellowships, and some positions often go unfilled. It should be possible to obtain fellowship dollars from industry manufacturers and pharmaceutical companies and bring surgeons from sub-Saharan Africa to the United States to fill those slots for additional training. It must be emphasized that this should not be used as a recruiting mechanism to increase the brain drain. Finally, working with the World Health Organization and the United Nations, the brain drain of physicians and nurses must be halted. Developed countries must agree not to recruit healthcare professionals from developing countries and, instead, should cooperate with the developing countries to provide education and training.

\section{Summary}

It is clear from this review and history that trauma care and trauma systems are in their infancy worldwide. Some countries are ahead of others, but very few countries, if any, can state that they have a perfect system. I think it can also be appreciated that in a global economy, the medical world is flat too. Professional resources such as doctors and nurses can be recruited, but this is not in the best interest of the countries doing the recruiting, and certainly not for the countries from which these professionals come.

\section{References}

1. Friedman T (2006) The world is flat: a brief history of the twentyfirst century. New York: Farrar, Strausand Giroux

2. Barlett DL, Steele JB (2006) Critical condition, Broadway Books, NY

3. Trunkey DD (2006) A growing crisis in patient access to emergency surgical care: a different interpretation and alternative solutions. ACS Bull 2-22

4. Murray CJL, Lopez AD (1996) The global burden of disease. Harvard University Press for the World Health Organization, Cambridge, MA

5. Trunkey DD (2000) History and development of trauma care in the United States. Clin Orthop Relat Res 374:36-46

6. Trunkey DD (1983) Trauma. Sci Am 249:29-35

7. Cales RH, Trunkey DD (1985) Preventable trauma deaths: a review of trauma care system development. JAMA 254:10591063

8. Smith RF, Frateschi L, Sloan EP et al (1990) The impact of volume on outcome in seriously injured trauma patients: two years experience of the Chicago trauma system. J Trauma 30:1066-1076

9. Mullins RJ, Veum-Stone J, Hedges J et al (1994) Influence of a statewide trauma system on location of hospitalization and outcome of injured patients after institution of trauma system in an urban area. JAMA 271:1919-1924

10. West JG, Williams MJ, Trunkey DD et al (1988) Trauma systems: current status - future challenges. JAMA 259:3597-3600

11. Bazzoli GJ, Madura KJ, Cooper GF et al (1995) Progress in the development of trauma systems in the United States. JAMA 273:395-401

12. Bazzoli GJ (1999) Community-based trauma system development: key barriers and facilitating factors. J Trauma 47(3 Suppl):S22-S24

13. MacKenzie EJ (1999) Review of evidence regarding trauma system effectiveness resulting from panel studies. J Trauma 47(3 Suppl):S34-S41

14. Mullins RS, Velum-Stone J, Hedges JR et al (1996) Influence of a statewide trauma system on location of hospitalization and outcome of injured patients. J Trauma 40:536-546 
15. MacKenzie EJ, Hoyt DB, Sacra JC et al (2003) National inventory of hospital trauma centers. JAMA 289:1515-1522

16. MacKenzie EJ, Rivara FP, Jurkovich GJ et al (2006) A national evaluation of the effect of trauma-center care on mortality. N Engl J Med 354(4):366-378

17. Papa L, Langland-Orban B, Flint L et al (2006) Assessing effectiveness of a mature trauma system: association of trauma center presence with lower injury mortality rate. J Trauma 61(2):261-266; discussion 266-267

18. Liberman M, Mulder D, Sampalis JS et al (2003) Multicenter Canadian study of prehospital trauma care. Ann Surg 237(2):161162

19. Liberman M, Mulder DS, Jurkovich GJ et al (2005) The association between trauma system and trauma center components and outcome in a mature regionalized trauma system. Surgery 137(6):647-658

20. Arreola-Risa C, Mock CN, Jurkovich GJ et al (1995) Trauma care systems in urban Latin America: the priorities should be prehospital and emergency room management. J Trauma 39(3):457-462

21. Arreola-Risa C, Speare JOR (1999) Trauma in Mexico. Trauma Q 14(3):211-220

22. Arreola-Risa C, Mock C, de Boer M et al (2006) Evaluating trauma care capabilities in Mexico with the World Health Organization guidelines for essential trauma care publication. Rev Panam Salud Publica 19(2):94-103

23. World Health Organization (2005) Prehospital trauma care systems. World Health Organization, Geneva. Available at http://www.who.int/publication/en/

24. World Health Organization (2004) Guidelines for essential trauma care. World Health Organization, Geneva. Available at http://www.who.int/publication/en/

25. Feoli E, Badilla V, Bermudez M et al (2002) Surgery in Costa Rica. Arch Surg 137:1435-1440

26. Scarpelini S, de Andrade JI, Passos ADC (2006) The TRISS method applied to the victims of traffic accidents attended at a tertiary level emergency hospital in a developing country. Sci Direct 37(1):72-77

27. Yates DW, Woodford M, Hollis S (1992) Preliminary analysis of the care of injured patients in 33 British hospitals: first report of the United Kingdom major trauma outcome study. BMJ 305:237240

28. Nicholl J, Turner J (1997) Effectiveness of a regional trauma system in reducing mortality from major trauma: before and after study. BMJ 315:1349-1354

29. Oakley PA, Kirby RM, Redmond AD et al (1998) Improvements have occurred since study [Letter]. BMJ 316:1382

30. Parr MJA, Nolan JP (1998) Wrong comparisons were made [Letter]. BMJ 316:1383

31. Wright J (1998) Data do not support conclusions [Letter]. BMJ 316:1383

32. Nicholl J, Turner J (1998) Authors' reply [Letter]. BMJ 316:1383

33. Edinburgh orthopaedic trauma unit. Available at http://www.trauma.co.uk/history.htm

34. Schmidt U (1999) The German trauma system: infrastructure and organization. Trauma Q 14(3):227-231

35. Pape H, Oestern HJ, Leenen L et al (2000) Documentation of blunt trauma in Europe. Eur J Trauma 5:233-247

36. Westhoff J, Hildebrand F, Grotz M et al (2003) Trauma care in Germany. Injury 34:674-683

37. ten Duis HJ, van der Werken C (2003) Trauma care systems in The Netherlands. Injury 34:722-727

38. Leppäniemi A (2005) Trauma systems in Europe. Curr Opin Crit Care 11:576-579

39. Trunkey DD (2005) Trauma in modern society: major challenges and solutions. Surgeon 3(3):165-170
40. Nijs SJB, Broos PLO (2003) Trauma care systems in Belgium. Injury 34:652-657

41. Guenther S, Waydhas C, Ose C et al (2003) Quality of multiple trauma care in 33 German and Swiss trauma centers during a 5-year period: regular versus on-call service. J Trauma 54(5):97-98

42. Uranüs S, Lennquist S (2002) Trauma management and education in Europe: a survey of twelve geographically and socioeconomically diverse European countries. Eur J Surg 168:730-735

43. Hamam AM, El-Sayed HF (1999) Injury in Egypt: the hidden epidemic. Trauma Q 14(3):261-267

44. Mock C (1999) Traumatic injury as a health problem worldwide. Trauma Q 14(3):191-196

45. Mock C, Quansah R, Krishnan R et al (2004) Strengthening the prevention and care of injuries worldwide. Lancet 363:21722179

46. Mock C, Quansah R, Addae-Mensah L et al (2005) The development of continuing education for trauma care in an African nation. Injury 36:725-732

47. Mock C, Adjei S, Acheampong F et al (2005) Occupational injuries in Ghana. Int J Occup Environ Health 11(3):238-245

48. Mock CN, Forjuoh SN, Rivara FP (1999) Epidemiology of transport-related injuries in Ghana. Accid Anal Prev 31(4):359370

49. Forjuoh SN, Mock CN, Freidman DI et al (1999) Transport of the injured to hospitals in Ghana. Accid Anal Prev 3:66-70

50. Adeyemi-Doro HO, Sowemimo GOA (1999) Optimal care for trauma victims in Nigeria. Trauma Q 14(3):295-300

51. Solagberu BA, Kuranga SA, Adekanye AO et al (2003) Preventable trauma deaths in a country without emergency medical services. Afr J Trauma 1:39-44

52. Matzopoulos RG, Prinsloo MR, Bopape JL et al (1999) Estimating the South African trauma caseload as a basis for injury surveillance. South African Medical Research Council

53. Wang Z, Jiang J (1999) Current status of trauma care in China. Trauma Q 14(3):233-240

54. Joshipura MK, Shah HS, Patel PR et al (2004) Trauma care systems in India - an overview. Indian J Crit Care Med 8:93-97

55. Sethi AK, Tyagi A (2001) Trauma untamed - as yet. Trauma Care 11(5):89-90

56. Mashiko K (2005) Trauma systems in Japan: history, present status and future perspectives. J Nippon Med Sch 72(4):194-202

57. Kobayashi K (1999) Trauma care in Japan. Trauma Q 14(3):249_ 252

58. Matsumoto H, Mashiko K, Hara $Y$ et al (2006) Effectiveness of a "doctor-helicopter" system in Japan. Isr Med Assoc J 8:8-11

59. Henman P (1999) War surgery - the temporary expatriate surgeon in a conflict zone. Trauma Q 14(3):311-322

60. Trunkey DD (2002) In search of solutions. J Trauma 53:1189_ 1191

61. U.S. GAO (1992) Operation Desert Storm: Full Army medical capability not achieved. U.S. General Accounting Office, Washington, DC, GAO/NSIAD-92-175

62. U.S. GAO (1993) Operation Desert Storm: Full Army medical capability not achieved. U.S. General Accounting Office, Washington, DC, GAO/NSIAD-93-189

63. U.S. GAO (1993) Operation Desert Storm: problems with Air Force medical readiness. U.S. General Accounting Office, Washington, DC, GAO/NSIAD-94-58

64. U.S. GAO (1996) War time medical care: DOD is addressing capability shortfalls, but challenges remain. U.S. General Accounting Office, Washington, DC, GAO/NSIAD-96-224

65. U.S. GAO (1996) War time medical care: personnel requirements still not resolved. U.S. General Accounting Office, Washington, DC, GAO/NSIAD-96-173 
66. Holcomb JB (2005) The 2004 Fitts Lecture: current perspective on combat casualty care. J Trauma 59(4):990-1002

67. Vassar MJ, Holcroft JJ, Knudson MM et al (2003) Fractures in access to and assessment of trauma systems. J Am Coll Surg 197:717-725

68. Cooper RA, Getzen TE, McKee HF et al (2002) Economic and demographic trends signal an impending physician shortage. Health Affairs 21:140-154

69. Cooper RA (2004) Weighing the evidence for expanding physician supply. Ann Intern Med 141:705-714

70. Bland KI, Isaacs G (2002) Contemporary trends in student selection of medical specialties. Arch Surg 137:259-267

71. Esposito TJ, Maier RV, Rivara FP et al (1991) Why surgeons prefer not to care for trauma patients. Arch Surg 126:292-297

72. Trunkey DD, Cahn RM, Lenfesty B et al (2000) Management of the geriatric trauma patient at risk of death. Arch Surg 135:34-38

73. U.S. GAO (1998) Traumatic brain injury: programs supporting long-term services in selected states. U.S. General Accounting Office, Washington, DC, GAO/HEHS-98-55

74. Gavrilova NNS, Semyonova VG, Evdokushkina G et al (2005) Problems with mortality data in Russia. Population Association of America annual meeting
75. Yuen WK, Chung CH (1999) Trauma care in Hong Kong. Trauma Q 14(3):241-247

76. Joshipura M, Mock C, Goosen J et al (2004) Essential trauma care: strengthening trauma systems around the world. Injury 35(9):841-845

77. Kumar S (2004) Report highlights shortcomings in private medical schools in India. BMJ 328:70

78. Project for development of the trauma center complex, Japan International Cooperation Agency, 2004. Available at http://www.jica.go.jp/english/evaluation/project/term/as/2004/ tha $02 . h t m$

79. Yeoh E (1999) Trauma care in Malaysia. Trauma Q 14(3):253260

80. Brooks A, Macnab C, Boffard K (1999) South Africa. Trauma Q 14(3):301-310

81. Garrett L (2007) Do no harm: the global health challenge. Foreign Affairs 86:14-38 